\title{
Carbon Footprint as Prominent Indicator of Agricultural Sustainability in Diverse Agro-climatic Zones of Northern India: A Critical Review
}

\author{
M. Sharath Chandra ${ }^{1 *}$, R.K. Naresh ${ }^{1}$, Pradeep Rajput ${ }^{1}$, Pebbeti Chandana ${ }^{2}$, \\ Pradeep Kumar Singh ${ }^{1}$ and K. Shivashankar ${ }^{3}$
}

\author{
${ }^{1}$ Department of Agronomy, Sardar Vallabhbhai Patel University of Agriculture \& Technology, \\ Meerut, U.P., India \\ ${ }^{2}$ Department of Agronomy, Tamil Nadu Agricultural University, Coimbatore, India \\ ${ }^{3}$ Department of Agronomy, University of Agricultural Sciences, Dharwad, Karnataka, India
}

*Corresponding author

\section{Keywords \\ Carbon footprint, Global warming, Greenhouse gas emission, Residue burning, Sustainability \\ Article Info \\ Accepted: 22 October 2020 Available Online: 10 November 2020}

\section{A B S T R A C T}

The human population on the planet is estimated to reach 9 billion by 2050; this requires significant increase of food production to meet the demands. Intensified farming systems have been identified as a viable means to increase grain production. Crop production inputs include carbon investment in the form of energy, for the manufacture and use of farm machinery, synthetic fertilizers, crop protection chemicals such as herbicides, insecticides and fungicides, groundwater irrigation and the direct use of fuel in farm operations. Such production technology operations in the agriculture sector contribute to Greenhouse Gas (GHG) emissions. On-farm cultivation operations also result in the loss of soil organic matter (SOM), hence another source of carbon (C) emission. Changes in cropland use and management practices influence direct and indirect energy consumption and emission of GHGs. The latest GHG inventory for India shows that the contribution of agriculture to country's total emissions is 18 per cent, of which about 21 per cent is related to nitrous oxide (N2O) emissions from agricultural soils and 18 per cent to rice production. Green revolution technologies in diverse agro-climatic zones of Northern India have led to the overexploitation of the natural resources, especially groundwater. Moreover, GHG driven changing climate is adding to the environmental woes. Under such complex situations, firstly, it becomes very important to register the effect of each management activity on the overall $\mathrm{C}$ footprint of crop production. Secondly, as the areal distribution of crops, groundwater extraction and fertilizer consumption has changed invariably within different agro climatic zones of Northern India over time, thus, it is important to do spatiotemporal analysis of the change in $\mathrm{C}$ use efficiency, net $\mathrm{C}$ returns and $\mathrm{C}$ cost per unit of production in different crops. With increase in production level of crops, mainly sugarcane and cereal crops the amount of their residues, subjected to field burning, also grew from $15.9 \%$ in $2008-09$ to $24 \%$ in 2016-17. Sustainability indices, based on inputs and outputs, helped identify crops with lower carbon footprint or more carbon efficient crops. Such spectacular gains in food grain production were mainly because of increased yields resulting from improved crop varieties combined with greater use of fertilizers, irrigation, plant protection chemicals, and other technologies associated with the 'Green Revolution'. However, these gains in food grain production have come at a cost to the environment. During the last 40 years (1970 to 2010), emission of greenhouse gases (GHGs) from the agriculture sector has increased by 35 percent, from 4.2 to $5.7 \mathrm{Gt} \mathrm{CO} \mathrm{eq} \mathrm{yr}{ }^{-1}$ (Gt or Giga tonne = $10^{15} \mathrm{~g} ; \mathrm{CO}_{2}=$ carbon dioxide). The increase has been greater during the decade 2000-2010, when agricultural emissions increased by 1.1 percent annually. Thus, there is a need for sustainable intensification of production systems for maintaining high yields without compromising the environmental integrity. 


\section{Introduction}

Agriculture is an important sector of the economy in India, contributing about $20 \%$ of national gross domestic product, and providing a livelihood for nearly two-thirds of the population (ICAR, 2015) (1) (Fig. 1). Equally important is the contribution of agriculture to national food security. India achieved self-sufficiency in food production after the Green Revolution (GR), but retaining this success has been challenging due to the increasing scarcity of resources, including labour, water, energy, and rising costs of production (Saharawat et al., 2010) (2). Increased use of production inputs, such as mineral fertiliser, has made Indian agriculture more greenhouse gas (GHG)-intensive. Agricultural production is a major emitter of GHGs, currently accounting for $18 \%$ of total GHG emissions in India (INCCA, 2010) (3). Recent estimates report that global food production must increase by $70 \%$ to meet the projected food demand of the estimated 9 billion global population by 2050 (CTACCAFS, 2011) (4). With a population of $\sim 1.3$ billion, it is evident that the food system in India will be central to the global challenge of providing sufficient nutritious food while minimising GHG emissions. However, given the increasing population and shifting dietary patterns, GHG emissions from agricultural production in India are expected to change.

In India, the majority of agricultural GHG emissions occur at the primary production stage (Pathak et al., 2010) (5), and are generated through the production and use of agricultural inputs, farm machinery, soil disturbance, residue management and irrigation. These practices are used to increase yields and improve harvests. Due to its direct contribution to global GHG emissions, agriculture can also serve as an important climate change mitigation strategy (Smith et al., 2013) (6), both by reducing GHG emissions to the atmosphere, and by sequestering atmospheric carbon into plant biomass and soil, though the role of some soil carbon sequestration practices for climate mitigation has been questioned (Powlson et al., 2014) (7).

Agriculture sector contributes to GHG emissions through energy use in the production and use of farm machinery, synthetic fertilizers, and crop protection chemicals such as herbicides, insecticides and fungicides and by direct use of fuel in farm operations. Cultivation or ploughing of soil resulting in the loss of soil organic matter (SOM), is another source of carbon (C) emission. Changes in cropland use and management influence direct and indirect energy consumption and emission of GHGs.The latest GHG inventory for India shows that the contribution of agriculture to country's total emissions is 18 percent, of which about 21 percent is related to nitrous oxide $\left(\mathrm{N}_{2} \mathrm{O}\right)$ emissions from agricultural soils and 18 percent to rice production (Government of India 2015) (8). Northern India, pioneer of India's Green Revolution, has sustained some negative effects of green revolution technologies in terms of overexploitation of the natural resources, especially groundwater. Therefore, to develop sustainable agricultural management strategies, it is important to enumerate the effect of each management activity on the overall $\mathrm{C}$ footprint of the crop production. Since the areal distribution of crops, groundwater extraction and fertilizer consumption has differentially changed within diverse zones of Northern India over time, thus, it is important to study the change in carbon use efficiency in terms of time and space as well. Such information will allow policy makers and extension experts to make appropriate decisions for efficient utilization of resources and prioritize areas for sustainable agriculture management. 
Uttar Pradesh is the largest producer of food grains in India and accounted for about 17.83 per cent share in the country's total food grain output in 2016-17. Food grain production in the state in 2016-17 stood at 49,144.6 thousand tonnes. Pulses production in the state stood at 1,985.00 thousand tonnes in 2017-18*.Major food grains produced in the state include rice, wheat, maize, millet, gram, pea \& lentil. With overall vegetable production of 28,226.19 thousand tonnes in 2017-18, the state remains largest producer of vegetables in India [Uttar Pradesh State Report - 2018 (10)] (Table 1-4).

\section{GHG emissions}

In the global context of addressing climate change, the key GHGs are carbon dioxide $\left(\mathrm{CO}_{2}\right)$, methane $\left(\mathrm{CH}_{4}\right)$, nitrous oxide $\left(\mathrm{N}_{2} \mathrm{O}\right)$, ozone $\left(\mathrm{O}_{3}\right)$, and chlorofluorocarbon (CFC). The GHG emissions from agriculture and allied sectors are mainly $\mathrm{CO}_{2}, \mathrm{CH}_{4}$, and $\mathrm{N}_{2} \mathrm{O}$ (Paustian 2016) (12). Further, only non- $\mathrm{CO}_{2}$ sources are considered anthropogenic GHG emissions from agriculture. The $\mathrm{CO}_{2}$ released from agriculture is considered neutral due to photosynthesis and fixation (IPCC 2007) (13). The high level of GHG emissions from agriculture is due to application of organic and inorganic inputs to the soil for crop production, decomposition of biomass and dead plant residues, crop production, plant respiration, livestock rearing, enteric fermentation in ruminants, manure handling, and burning of crop residues (IPCC 2007) (13) and savanna (Russell-Smith et al., 2017) (14) (Fig. 2a). GHG emissions are caused not only by agriculture and food production but also by transportation, postharvest activities, and cooking of food (Kehlbacher et al., 2016) (15). The agricultural sector is responsible for approximately 10-12 percent of total anthropogenic GHG emissions (FAO 2016). The emission trends sector by sector (Fig. 2b). Notably, all the sectors except AFOLU observed an annual growth rate of approximately $3-9 \%$. It is also notable that while the emissions from the agriculture sector (excluding LULUCF) were increasing from 2005(335 Million tonnes $\mathrm{CO}_{2} \mathrm{e}$ ) to 2011 (352 Million tonnes $\mathrm{CO} 2 \mathrm{e}$ ), there was a decline in the year 2012 (348Million tonnes $\mathrm{CO}_{2} \mathrm{e}$ ) and emissions from AFOLU have declined thereafter mainly due to a stagnation in the growth of population of cattle and increase in removals from the forestry sector. The compounded annual declines in emissions from AFOLU in the reporting period were $1.9 \%$ (GHG Platform-India, 2017) (16).

Agriculture is the largest source of emissions of $\mathrm{N}_{2} \mathrm{O}$ (Reay et al., 2012) (18). $\mathrm{N}_{2} \mathrm{O}$ is 298 times more effective than $\mathrm{CO}_{2}$ at trapping heat in the atmosphere. In India, agriculture accounts for approximately 58percent of total emissions of $\mathrm{N}_{2} \mathrm{O}$, which are mostly, caused by application of fertilizers (FAO 2009) (19).The Ministry of Environment and Forests (MoEF 2010) (20) estimated that $\mathrm{N}_{2} \mathrm{O}$ is responsible for approximately13 percent of Indian agricultural GHG emissions. Further, crop residues and the burning of crop fields/residues also contribute significantly to GHG emissions. Crop residues left on managed fields contain significant amounts of nitrogen and produce $\mathrm{N}_{2} \mathrm{O}$ through the process of decomposition, while the burning of crop residues or vegetation usually releases $\mathrm{CO}_{2} ; \mathrm{CH}_{4} ; \mathrm{N}_{2} \mathrm{O}$; and other ozone precursors; and aerosols (including black carbon) into the atmosphere (IPCC, 2014) (21). Globally, the burning of savanna and crop residues accounts for approximately 6 percent of total emissions from agriculture, but for India the amount is less than 1 percent (FAO, 2016 (22)).

Chakrabarty (2018) (24) reported that from 2005 to 2013, India emitted 20.54 billion tons of carbon dioxide equivalents $\left(\mathrm{CO}_{2} \mathrm{e}\right)$, with 
emissions growing annually by 5.57 percent. Emissions per capita grew, too, by 4.07 percent annually. In the year 2013, India emitted 2.8 gigatons $\mathrm{CO}_{2} \mathrm{e}$ - less than the U.S. (6.2 gigatons $\mathrm{CO}_{2} \mathrm{e}$ ) or China (11 gigatons $\left.\mathrm{CO}_{2} \mathrm{e}\right)$.

\section{Carbon equivalent emissions from inputs}

Carbon equivalent (CE) emissions from inputs were based on- i) rates of fertilizer $(\mathrm{N}$, $\mathrm{P}$ and $\mathrm{K}$ ) and pesticides application to each crop, ii) irrigation water requirement of each crop and water management practices involving groundwater (tube well) or surface water (canal) irrigations, and iii) crop-specific farming practices (seed-bed preparation, tillage etc.) and farm power used for various operations (seeding, harvesting and threshing). In addition to aforementioned emissions, other sources of GHGs were methane emission from rice paddies, direct $\mathrm{N}_{2} \mathrm{O}$ emissions from nitrogenous fertilizers and emissions from burning of crop residues. Input based $\mathrm{CE}$ emissions were computed individually for each crop grown in a district and summed for all crops to calculate total emissions in a district and eventually for the state. Total emissions for a given crop in the whole state were computed by adding emissions from that crop in different districts. The results were expressed in CE using appropriate conversion factors (Fig. 3).

\section{Fertilizers}

Data on seasonal (kharif and rabi) consumption of fertilizer $\mathrm{N}, \mathrm{P}_{2} \mathrm{O}_{5}$ and $\mathrm{K}_{2} \mathrm{O}$ in different districts of Uttar Pradesh, Punjab and India (Fertilizer Association of India 1981, 1991, 2001, 2011 and 2017) were converted to per ha seasonal consumption based on the cropped area during each season. The fertilizer consumption during each season was apportioned to various crops considering their nutrient requirement. Firstly, total NPK consumption by kharif/rabi pulses and oilseeds was computed based on the area under pulses and oilseeds.

Punjab Agricultural University recommended fertilizer application rates for pulses $(15 \mathrm{~kg} \mathrm{~N}$ and $30 \mathrm{~kg} \mathrm{P} \mathrm{P}_{2} \mathrm{O}_{5} \mathrm{ha}^{-1}$ ) and oilseeds $(60 \mathrm{~kg} \mathrm{~N}$ and $30 \mathrm{~kg} \mathrm{~K}_{2} \mathrm{O} \mathrm{ha}^{-1}$ ) were used to calculate fertilizer consumption by these crops. Consumption of potassium in legumes/pulses and oilseeds was assumed to be zero. Thereafter, NPK consumption was calculated for kharif/rabi cereals and other crops by subtracting the total amount consumed by kharif/rabi pulses and oilseeds from the total NPK consumed by all crops during a season. Based on per ha seasonal NPK consumption, per ha CE emissions were computed and were then used to compute total emissions from a given crop.

Though fertilizers per se do not emit $\mathrm{CO}_{2}$ yet there are hidden C-costs associated with manufacturing, packaging, transportation and application of fertilizers. Estimates of hidden C-cost of fertilizers range between 0.9 and 1.8 $\mathrm{kg} \mathrm{C} \mathrm{kg}^{-1} \mathrm{~N}, 0.1$ to $0.3 \mathrm{~kg} \mathrm{C} \mathrm{kg}^{-1} \mathrm{P}_{2} \mathrm{O}_{5}$ and 0.1 to $0.2 \mathrm{~kg} \mathrm{C} \mathrm{kg}^{-1} \mathrm{~K}_{2} \mathrm{O}$ (Lal 2004) (25). In this study, the $\mathrm{C}$ cost used for $\mathrm{N}, \mathrm{P}_{2} \mathrm{O}_{5}$ and $\mathrm{K}_{2} \mathrm{O}$ were $1.3,0.20$, and $0.15 \mathrm{~kg} \mathrm{C} \mathrm{kg}^{-1}$, respectively.

\section{Irrigation}

Irrigation water requirement of a crop depends on seasonal evapotranspiration (ET), percolation and rainfall

Irrigation water $=(\mathrm{ET}+$ Percolation $)-$ Rainfall

Evapotranspiration plus percolation for different crops in Punjab range between 320 and $2050 \mathrm{~mm}$ with highest for rice and the lowest for winter-sown oilseed crops (Table 5). Growing season rainfall for each crop in a 
district was computed as average (crop season) of 5 years (the study year and 4 preceding years). For instance, 1976-1980, 1986-1990, 1996-2000, 2006-2010 and 20122016 for the study years 1980-81, 199091,2000-01, 2010-11 and 2016-17, respectively. Seasonal rainfall for each crop in a district was computed from monthly rainfall data for the district.

\section{Plant protection chemicals}

Like fertilizers, there are hidden C-costs associated with manufacturing, packaging, transportation and application of pesticides. Each pesticide has different C-costs associated with its manufacture, transport and application. Because of lack of data on consumption of individual plant protection chemicals in different crops, consumption rate $\left(\mathrm{g} \mathrm{ha}^{-1}\right.$ ) was calculated from the total plant protection chemicals consumed and the gross area sown. The consumption rate was used to calculate total $\mathrm{CE}$ emissions by multiplying the amount of chemical consumed with an emission factor of $4.93 \mathrm{~kg} \mathrm{C} \mathrm{kg}^{-1}$ of product.

\section{Farm operations}

Total energy consumed per ha to perform different farm operations for a given crop was multiplied with the total area under the crop to compute total $\mathrm{CE}$ emissions from field preparation, seeding, harvesting and threshing. Tillage for seedbed preparation, which involves disturbance of soil, is an important source of $\mathrm{CO}_{2}$.

The tillage methods prevalent in the state include disk harrow and tine-cultivation. Crop-specific tillage operations were identified, and CE emissions were estimated based on the $\mathrm{C}$ emission factors for different types of machinery (Table 6). Emission factors were developed for agricultural machinery based on the technical specifications of locally-used machines and diesel consumed per ha for one operation. Carbon emissions from diesel consumption for an operation were calculated from the ratio of $\mathrm{C}$ emission to energy content of diesel $(0.0732 \mathrm{~kg} \mathrm{C}$ per $\mathrm{kWh})$. Carbon cost associated with the manufacture and transport of machinery was not considered. Carbon emissions for a mechanized field operation were calculated for each crop as the product of number of operations, emission factor for the machinery and the area under the crop (Benbi, 2019) (27).

The total input-based $\mathrm{CE}$ emissions were computed by adding emissions from all the inputs viz fertilizers, plant protection chemicals, irrigation tillage and other farm operations.

\section{Methane emission from rice fields}

Methane $\left(\mathrm{CH}_{4}\right)$ emission occurs from rice fields due to prevalence of reduced conditions with submergence. The intensity of emissions depends on irrigation water management. Rice area in different districts was divided into three irrigation regimes viz. continuously flooded (CF), intermittently flooded with single aeration (IFSA) and intermittently flooded with multiple aerations (IF-MA). In different districts, 0 to 10 percent area fell into continuously flooded, 30 percent into intermittently flooded with single aeration and 60-70 percent under intermittently flooded with multiple aerations. Such irrigation regime values were arrived at based on expert opinion, soil type and water availability in a district. Methane emissions from rice fields under different hydrology were calculated using region-specific emission factors of 55.7, 34.5 and $23.3 \mathrm{~kg} \mathrm{CH}_{4} \mathrm{ha}^{-1}$ for CF, IFSA and IF-MA, respectively (Khosa et al., 2011). Methane emissions were converted to $\mathrm{CE}$ emissions using a Global Warming Potential of 28 (IPCC, 2013) (28). 


\section{Nitrous oxide emission}

Direct Nitrous oxide $\left(\mathrm{N}_{2} \mathrm{O}\right)$ emissions from applied fertilizer $\mathrm{N}$ were computed using emission factor of $0.0065 \mathrm{~kg} \mathrm{~N} \mathrm{~N}_{2} \mathrm{O}-\mathrm{N} \mathrm{kg}^{-1}$ fertilizer N (Garg et al., 2012) (29). $\mathrm{N}_{2} \mathrm{O}-\mathrm{N}$ emissions for each district were calculated as per equation and converted to $\mathrm{CE}$ emissions using a100-years Global Warming Potential (GWP) of 265.

$\mathrm{N}_{2} \mathrm{O}-\mathrm{N}$ emissions $=$ Fertilizer $\mathrm{N} * \mathrm{E}_{\mathrm{f}}$

Where Fertilizer $\mathrm{N}$ is rate of synthetic fertilizer $\mathrm{N}$ applied to soil $\left(\mathrm{kg} \mathrm{N} \mathrm{yr}^{-1}\right), \mathrm{E}_{\mathrm{f}}$ is emission factor for $\mathrm{N}_{2} \mathrm{O}$-Nemissions from synthetic fertilizer $\mathrm{N}\left(\mathrm{kg} \mathrm{N}_{2} \mathrm{O}-\mathrm{N} \mathrm{kg}^{-1}\right.$ fertilizer N) (Fig. 4).

\section{Emissions from crop residue burning}

A district-wise inventory of $\mathrm{CO}_{2}, \mathrm{CO}, \mathrm{CH}_{4}$ and $\mathrm{N}_{2} \mathrm{O}$ emissions from burning of crop residues was prepared for different years using the IPCC (2006) guidelines. Rice, wheat and sugarcane stubble is mainly burnt to facilitate the sowing of the next crop in the rotation. Crop productivity/production values collected from Statistical Abstracts of Punjab for different years were used to compute residue produced per ha or total residue production.

Emission from open field burning of crop residue (FBCR) was calculated using equation below.

\section{FBCR $=\Sigma \operatorname{crops}(\mathrm{P} \times \mathrm{Rf} \times$ DMf $\mathrm{x}$ Bf $\mathrm{x}$ Of $\mathrm{x}$} $\mathrm{EF})$

Where, $\mathrm{P}$ is the crop production, $\mathrm{R}_{\mathrm{f}}$ is the residue to crop ratio, DMf is the dry matter fraction, $\mathrm{Bf}$ is the fraction burnt, Of is the fraction actually oxidized, EF is the emission factors for different GHGs. The amount of rice residue burnt during the years 1980-81 to
2000-01, was calculated as a field fraction (0.80) of the crop residue produced. Whereas for 2010-11 and 2016-17 it was calculated from the satellite observation data (PRSC 2015 \& Pers. Comm. 2017) of rice area burnt in different districts. For wheat and sugarcane, the fraction of crop residue burnt was 0.15 and 0.10 , respectively. The emission factors, which represent the amount of a pollutant released per unit of dry fuel consumed, were obtained from Andreae and Merlet (2001) (30). These were $\left(\mathrm{g} \mathrm{kg}^{-1}\right.$ dry matter burned) $1515,92,2.7$, and 0.07 for $\mathrm{CO}_{2}, \mathrm{CO}, \mathrm{CH}_{4}$, and $\mathrm{N}_{2} \mathrm{O}$ respectively. The $\mathrm{CO}_{2}$ emission factor for burning of rice residue was taken as $1460 \mathrm{~g} \mathrm{~kg}^{-1}$ dry matter burned (Gadde et al., 2009) (31). These were converted to $\mathrm{CE}$ emissions using 100-years GWP of 265, 28 and 1.8, for $\mathrm{N}_{2} \mathrm{O}, \mathrm{CH}_{4}$ and $\mathrm{CO}$, respectively.

\section{Carbon equivalent outputs}

Carbon equivalent output comprised of aboveground crop biomass encompassing grain or economic Yield and straw yield, stubble and leaf litter and belowground root biomass. Information on crop production or productivity collated from Statistical Abstracts of Punjab was used to calculate the straw or residue produced using crop specific harvest indices (Table 7). Root biomass values were derived from aboveground biomass using shoot/root ratios for different crops. All the components were converted to $\mathrm{CE}$ using plant $\mathrm{C}$ content of 40 percent.

\section{Components of carbon footprint}

\section{Carbon-based input}

Fertilizer consumption, groundwater irrigation, consumption of plant protection chemicals, tillage for seed-bed preparation and other farm operations comprised total $\mathrm{C}$ based input for a crop. 
The GHG emissions from Indian agriculture during 1970-2010 have increased by about $75 \%$. Increase use of fertilizers and other agriinputs and the rise in population of livestock are the major drivers for this increase in GHGs emissions (Fig. 5a). From 1970 to 2010, the emission of $\mathrm{CH}_{4}$ from Indian rice fields has remained almost similar though the rice production increased from $115 \mathrm{Mt}$ to 128 Mt. It is because of almost constant area under rice (43-44 $\mathrm{M}$ ha) and use of similar water and crop management practices by the farmers over the years. However, the emission of $\mathrm{N}_{2}$ Ohas increased considerably during this period because of the application of more fertilizers and manure in soil (Fig. 5b) (Pathak et al., 2014 (32)).

\section{Fertiliser based carbon equivalent emissions}

Use of nitrogenous fertilizer accounts for approximately 17.4 percent of agricultural GHG emissions from different districts of Uttar Pradesh i.e., Basti, Faizabad, Farrukabad, Jyotiba Phule Nagar, Muzaffarnagar, and Varanasi including other parts of India (Patra and Babu, 2017 (34)). Sapkota et al., (2019) (35) analysed the spatial distribution of the mitigation potential of efficient fertilizer use and rice-water management in order to identify mitigation hotspots at the scale at which policies are implemented in India. Our estimate shows that per-year GHG mitigation potential through reduced fertilizer consumption through precision nutrient management was highest in Uttar Pradesh (ca. $3.15 \mathrm{MtCO}_{2} \mathrm{e}$ ) followed by Andhra Pradesh (2.04 $\mathrm{Mt} \mathrm{CO}_{2} \mathrm{e}$ ), Maharasthra (1.72 $\left.\mathrm{MtCO}_{2} \mathrm{e}\right)$ and Punjab (1.5 $\left.\mathrm{MtCO}_{2} \mathrm{e}\right)$ Fig. $6 \mathrm{a}$.

The production of Major Chemicals in 201819 is 11,578 thousand MT, compared to 11,068 thousand MT during the same period in $2017-18$ implying a growth of $4.61 \%$. The
CAGR in production of total basic major Chemicals during the period 2014-15 to 201819 is $4.63 \%$. The trend in the production of selected major chemicals is depicted in Fig. 6b (GOI, Annual report 2018-19).

UP is the largest producer of food grains among all states in India and accounted for about 17.83 per cent share in the country's total food grain output in 2016-17. Food grain production in the state in 2017-18 stood at $51,252.7$ thousand tonnes and 18,416.3 thousand tonnes in 2018-19. Pulses production in the state stood at 2,208.0 thousand tonnes in 2017-18 (4 ${ }^{\text {th }}$ Advance estimates) and 660.7 thousand tonnes under kharif season in 2018-19 (1 ${ }^{\text {st }}$ Advance Estimates) (IBEF, 2019 (37)).

Tirado et al., (2010) (38) reported that Fertiliser Association of India from 1960-61 to 2006-07 of production and consumption of the various forms of synthetic $\mathrm{N}$ fertilizers in India (Fig. 7a, FAI, 2007 (39)) and used bestavailable specific emission factors to estimate GHG emissions according to Intergovernmental Panel on Climate Change (IPCC) (Fig. 7b). The total emissions from synthetic $\mathrm{N}$ fertilizer reached $100 \mathrm{Mt}$ of carbon dioxide equivalent $\left(\mathrm{CO}_{2}\right.$-e $)$ in 2006-07 and half of these emissions resulted from the $11 \mathrm{Mt}$ of synthetic $\mathrm{N}$ produced in the country during that year $\left(48 \mathrm{Mt}\right.$ of $\left.\mathrm{CO}_{2}-\mathrm{e}\right)$ and the other half resulted from the $14 \mathrm{Mt} \mathrm{N}$ applied in Indian farm soils the same year $(51 \mathrm{Mt}$ of $\mathrm{CO}_{2}$-e,ranging between 28 and 163 (up to $522) \mathrm{Mt}$ of $\mathrm{CO}_{2}$-e, depending on the emission factor used (Fig. 7c).

\section{Irrigation based carbon equivalent emissions}

Mishra et al., (2018) (40) reported that several factors affecting GHGs emission but water management in rice-wheat ecosystem plays crucial role in UP. It has been found that 
water regime in irrigated rice fields with large water percolation and scanting water supply; often lead to multiple aeration, which has a direct impact on $\mathrm{CH}_{4}$ emission. In wheat crop does not have water flooding due to $\mathrm{N}_{2} \mathrm{O}$ toxic environment. Irrigation-based $\mathrm{CE}$ emissions escalated 12.6-fold in rice; from $167 \mathrm{Gg}$ in $1980-81$ to $2112 \mathrm{Gg}$ in $2016-17$ (Fig. 8a). During the 37-years period, the emissions from irrigation increased at an average rate of $54 \mathrm{Gg} \mathrm{CE} \mathrm{yr}^{-1}$ but the rate was higher (82 Gg CE $\mathrm{yr}^{-1}$ ) during the decade 2000 to 2010. Increase in irrigation-based emissions was because of increased area under rice as well as higher per unit area emissions. Quantitatively, the area sown to rice increased 2.6-fold (from 1182 thousand ha in 1980-81 to 3046 thousand ha in 201617) and per unit area emissions increased 4.7fold (from 143 to $667 \mathrm{~kg} \mathrm{CE} \mathrm{ha}^{-1}$ ) during the 37-year period (Fig. 8b).

Mishra et al., (2018) (40) reported that the $\mathrm{CO}_{2}$ emissions due to bicarbonate $(\sim 0.72$ $\mathrm{MTyr}^{-1}$ ) are dominated by those due to groundwater pumping (31.29-131.02 $\mathrm{MTyr}^{-1}$ ) in India. However, the total (pumping and bicarbonate) estimated annual $\mathrm{CO}_{2}$ emission from groundwater is less than $2-7 \%$ of the total (annual) $\mathrm{CO}_{2}$ emission from India. A few regions (western India and Indo-Gangetic Plain) have more than $90 \%$ of their area irrigated with ground water resources. The net irrigated area from different sources, mainly tube wells, has increased (except for tanks) between 1950 and 2010 (Fig. 8a).

\section{Emissions from residue burning}

Agricultural crop residue burning contribute towards the emission of greenhouse gases $\left(\mathrm{CO}_{2}, \mathrm{~N}_{2} \mathrm{O}, \mathrm{CH}_{4}\right)$, air pollutants $\left(\mathrm{CO}, \mathrm{NH}_{3}\right.$, $\mathrm{NO}_{2}, \quad \mathrm{SO}_{2}, \quad \mathrm{NMHC}, \quad$ volatile organic compounds), particulates matter and smoke thereby posing threat to human health. Crop residues and burning of crop residues account for 4.7 percent of total agricultural emissions and are identified as EV-C. Uttar Pradesh (72 districts) have a high $\mathrm{EV}-\mathrm{C}$, between greater than or equal to 0.0306 and less than 0.0421 (Patra and Babu, 2017 (34)). Jain et al., (2014) (41) observed that the generation of cereal crop residues was highest in the states of Uttar Pradesh (72 Mt) followed by Punjab (45.6 Mt), West Bengal (37.3 Mt), Andhra Pradesh (33 Mt) and Haryana (24.7Mt). Uttar Pradesh contributed maximum to the generation of residue of sugarcane $(44.2 \mathrm{Mt})$ while residues from fibre crop was dominant in Gujarat (28.6 Mt) followed by West Bengal (24.4 Mt) and Maharashtra (19.5 Mt). Rajasthan and Gujarat generated about 9.26 and 5.1 Mt residues from oilseed crops (Fig.9a). Uttar Pradesh contributed maximum to the burning of sugarcane trash followed by Karnataka (Fig. 9b).

\section{Emissions from rice fields}

Ali et al., (2019) (43) revealed that rice paddy fields act as a source of greenhouse gases such as methane $\left(\mathrm{CH}_{4}\right)$ and nitrous oxides $\left(\mathrm{N}_{2} \mathrm{O}\right)$ depending on soil organic matter status, land use and cropping intensity, irrigation water and drainage management practices, soil microbial populations and their activities, soil properties, and climatic variables. The management practices such as tillage operations, levelling, plant residue incorporation, irrigation frequency and standing water levels, drainage system, and organic and inorganic soil amendments followed in rice farming influence the amount of $\mathrm{CH}_{4}$ and $\mathrm{N}_{2} \mathrm{O}$ emitted to the atmosphere. Generally, $\mathrm{CH}_{4}$ gas is produced under flooded or anoxic soil conditions (Fig.10a), while $\mathrm{N}_{2} \mathrm{O}$ gas is produced through nitrification and denitrification processes depending on soil aerobic (oxygenated) and anaerobic conditions (Fig. 10b).

Patra and Babu, (2017) (34) also found that the cultivation of rice, which emits $\mathrm{CH}_{4}$, accounts for15.1 percent of agricultural GHG 
emissions from different districts of Uttar Pradesh ie., Basti, Faizabad, Farrukabad, Jyotiba Phulenagar, Muzaffarnagar, and Varanasi including other parts of India. Gupta et al., (2009) (44) reported that using NATCOM EFs, the trend of national $\mathrm{CH}_{4}$ emission inventory from paddy fields during 1979 to 2006 has indicated the emission estimates and the variability in the range of $3.62 \pm 1$ to $4.09 \pm 1.19 \mathrm{Tg} \mathrm{y}^{-1}$ (Fig. 11a), with an insignificant growth rate of $0.004 \mathrm{Tg} \mathrm{y}^{-1}$ (Fig.11a) and uncertainty ranges in the $\mathrm{CH}_{4}$ emission estimates under different paddy water regimes for the period 1979-2006 are shown in Fig.11b. The states in India have been ranked according to their cumulative emissions in descending order (Fig. 11b).

Pathak et al., (2005) (45) reported that continuous flooding of rice fields (42.25 million ha) resulted in annual net emissions of 1.07-1.10,0.038-0.048 and 21.16-60.96 Tg of $\mathrm{CH}_{4}-\mathrm{C}, \quad \mathrm{N}_{2} \mathrm{O}-\mathrm{N}$ and $\mathrm{CO}_{2}-\mathrm{C}$, with accumulated global warming potential (GWP) of $\quad 130.93-272.83 \quad \mathrm{Tg} \quad \mathrm{CO}_{2}$ equivalent. Intermittent flooding of rice fields reduced annual net emissions to $0.12-0.13 \mathrm{Tg} \mathrm{CH}_{4}-$ Cand 16.66-48.80 Tg $\mathrm{CO}_{2} 15-\mathrm{C}$. While $\mathrm{N}_{2} \mathrm{O}$ emission increased to $0.056-0.060 \mathrm{Tg} \mathrm{N}_{2} \mathrm{O}$ N.The GWP, however, reduced to 91.73211.80 $\mathrm{Tg} \mathrm{CO}_{2}$ equivalents.

Since 1990, several estimates of $\mathrm{CH}_{4}$ emission from Indian rice fields have been made and the emission estimate has been rationalized from the earlier estimate of 37.5 Mt to 3.3 Mt (Fig. 12a). However, the estimates of $\mathrm{N}_{2} \mathrm{O}$ emission from agricultural soils have remained variable over the years (Pathak et al., 2014 (32), Fig. 12b).

\section{Emission from different crops}

Kumar et al., (2018) reported that western Uttar Pradesh, the production of maize has decreased drastically and $\mathrm{NO}_{2}$ have shown an increasing trend. The linear correlation between $\mathrm{NO}_{2}$ and maize production also seemed to be very low.Over the selected sites from north-west India, the production of rice and maize has reduced by $\sim 40 \%$ and the increase in greenhouse gases $\left(\mathrm{CO}_{2}, \mathrm{NO}_{2}\right.$ and $\mathrm{CH}_{4}$ ) was almost 5\% from 1998 to 2011 (Fig 13 a to $\mathrm{c})$.

\section{Sugarcane}

Among the states within India, Uttar Pradesh produces the largest quantity of sugarcane at nearly 129 million tonnes (Mt) per year (DoES, 2016) (47). In Uttar Pradesh, sugarcane is cultivated in 2,162,400 hectares (ha) of land, with the total sugarcane production equalling 129 million tonne (Mt) on annual basis (Table 8 and Table 9). The gross annual bagasse production is $38.65 \mathrm{Mt}$. Considering that $70 \%$ of the total produced bagasse is available as surplus, net annual bagasse availability for co-generation in the state is $27.05 \mathrm{Mt}$. Bagasse production at the agro-climatic zone level varies from a minimum of $34.42 \mathrm{kilo}$ tonne (kt, $0.13 \%$ of state total) in the Vindhyan zone to a maximum of $9,178.20 \mathrm{kt}$ (34\%of state total) in the western plain zone, as shown in Table 8. The major sugarcane belt of Uttar Pradesh is situated in the western plain and midwestern plain zones, which collectively contribute nearly $50 \%$ of total sugarcane production in Uttar Pradesh (Hiloidhari et al., 2018) (48).

Uttar Pradesh is divided into nine agroclimatic zones and seventy-two districts. The agro-climatic zones show a range of climatic conditions for the state, including dry conditions suited for Jatropha crops and rainintensive conditions that are more conducive to sugarcane. Nearly $78 \%$ of the total population live in rural areas, with agriculture being the major source of livelihood (Hiloidhari et al., 2018) (48). 
Singh and Sharma (2016) (50) observed that carbon dioxide $\left(\mathrm{CO}_{2}\right)$ exchange between sugarcane plant and the atmosphere is one of the key processes that affect atmospheric $\mathrm{CO}_{2}$ concentration and carbohydrate synthesis. His study was taken up during 2014-15, to assess the role of sugarcane cultivation in mitigating green house gases (GHGs), which is the main constituent of global warming, and to know the role of this crop in sequestering atmospheric $\mathrm{CO}_{2}$ concentration in India, as well as in Uttar Pradesh, which is the major contributor state of sugarcane in India. Analysis revealed that $\mathrm{CO}_{2}$ released by sugarcane crop in the field and during processing of the cane accounts for 20.65 million tons, however, the crop absorbed 228.89 million tons of $\mathrm{CO}_{2}$ from the Indian atmosphere during its life cycle. This indicates that 208.24 million tons of extra equivalent $\mathrm{CO}_{2}$ was absorbed from the atmosphere by the sugarcane crop planted in India (5.32 M ha) apart from $\mathrm{CO}_{2}$ released during its own respiration. This extra build up of $\mathrm{CO}_{2}$ in the air comes from different sources like other crops, soils, animals, burning, industries, etc. The extended study showed that out of 208.24 million tons of absorbed $\mathrm{CO}_{2}$ from Indian environment, sugarcane grown in Uttar Pradesh (2.1 M ha) absorbed 84.58 million tons contributing 40.61 percent of the total $\mathrm{CO}_{2}$ absorbed by the entire sugarcane crop grown in India which exhibited highest environmental cleaning over other states just like sugarcane production. The study stated that sugarcane crop plays an important role in purifying the air by acting as one of the potential $\mathrm{CO}_{2}$ scavengers. As carbon dioxide is most abundant constituent of the GHGs thus their decreased level may ultimately mitigate the level of GHGs from the environment in sugarcane growing areas of Uttar Pradesh as well as in India and thus may contribute in combating global warming.

Sugarcane crop is one among those crops that is able to cope up with the increasing level of
$\mathrm{CO}_{2}$ due to four natural endowments it possesses (Fig. 14a). Very low carbon dioxide compensation point and unique property of sequestering carbon in form of phytolith or planstone is some of the important natural endowment with respect to the rising $\mathrm{CO}_{2}$ concentration in atmosphere. Elevation in $\mathrm{CO}_{2}$ concentration affects yield of several crops; however, sugarcane is the crop which has been bestowed with two important abilities, viz., low compensation point (ranging between 0-10 ppm) and carbon sequestering ability (181 $\mathrm{kg} \quad \mathrm{C}$ is sequestered/ha year) that helps in managing the effect of higher concentration of $\mathrm{CO}_{2}$ on the crop. Moreover, sugarcane cultivation in the increasing scenario of $\mathrm{CO}_{2}$ will also be beneficial for the higher productivity and yield of other crops as it will be able to lower the concentration ofCO ${ }_{2}$ to some extent (Misra et al., 2019) (51).

Sugarcane has been bestowed with four natural endowments, viz, higher optimal temperature for growth processes, compensatory ability, low carbon dioxide compensation point and carbon sequestration ability in respect to increasing $\mathrm{CO}_{2}$ concentration that helps in showing better performance under highCO $\mathrm{O}_{2}$ concentrations in comparison to other crops (Misra et al., 2019) (51).

For sugarcane, Tamil Nadu reports the highest level of land productivity (105.3 t/ha) as well as PWP $\left(14.01 \mathrm{~kg} / \mathrm{m}^{3}\right)$. As in the case of rice, one observes somewhat perverse relation between land productivity and IWP in sugarcane also. The tropical belts of Uttarkhand, Uttar Pradesh and Bihar report higher levels of IWP but lower levels of land productivity (Fig.15b). At the same time, the sub-tropical belts of Tamil Nadu, Karnataka, Maharashtra and Andhra Pradesh have high land productivity but lower levels of IWP values. This indicates the stated mismatch between sugarcane cropping pattern and water 
resource availability, which needs to be corrected by suitably adjusting the price of power and irrigation water, and by promoting more efficient technologies (such as drip) for irrigating sugarcane crop in these regions. The sugar licensing policy of preferring cooperatives sugar factories over private ones was one of the major reasons for the shift in the sugarcane growing belt from Bihar and eastern Uttar Pradesh towards the water stressed sub-tropical belts of Maharashtra, Karnataka and Tamil Nadu. But this is not in line with water resource endowment of the region (Sharma et al., 2018) (53) (Table 9).

\section{Contribution of different crops}

Enumeration of the contribution of various crops towards total input based emissions showed that in 2016- 17 , rice and wheat contributed 2971 and $1530 \mathrm{Gg} \mathrm{CE}$, which respectively represented 63 and 33 per cent of the total emissions in croplands (Fig.15). The two crops together accounted for 81 and 96 per cent of emissions in 1980-81 and 201617 , respectively. The input based emissions in rice and wheat have been growing since198081.The emissions in rice went up by4.4-fold between1980-81 and 2000-01and further increased 2-fold during 2000-01 and 201617. The increase in emissions in wheat was relatively small. Despite starting with higher total emissions (590 Gg CE) compared to rice $(329 \mathrm{Gg})$ in 1980 , emissions in wheat were about half that of rice in 2016-17. The contribution of rice towards total emissions increased from 29 to 63 percent and that of wheat decreased from 52 to 33 percent over years. Maize contributed only $43 \mathrm{Gg} \mathrm{CE}$ in 2016-17 and its contribution towards total emissions declined from 5.5 to 0.9 percent. Cotton and sugarcane respectively contributed 76 and $60 \mathrm{Gg} \mathrm{CE} \mathrm{yr}^{-1}$ in 2016-17. The contribution of cotton declined from 7 to 1.6 percent while that of sugarcane remained between 1 and 2 percent throughout. The contribution of oilseeds and pulses together declined from 4.3 to 0.24 percent.

Segregating the contribution of various input sources towards total emissions in different crops showed that groundwater irrigation and fertilizer use together accounted for 89 to 96 percent of the emissions in rice during 198081 to 2016-17 and rest of the emissions originated mainly from tillage and other farm operations (3.4-10.7\%). Pumping of groundwater for irrigation was the most critical input source and its contribution towards total emissions in rice increased from about 51 percent in $1980-81$ to 71 percent in 2016-17. Contribution of tillage and other farm operation based emissions declined from 10.7 percent in $1980-81$ to 3.4 percent in 2016-17. Emissions from consumption of plant protection chemicals generally accounted for less than 1 percent of the total $\mathrm{CE}$ emissions. In sugarcane, irrigation accounted for 35 and 59 percent and fertilizer use accounted for 41 and 33 percent of the emissions in 1980-81 and 2016-17, respectively. In kharif and rabi pulses, the contribution of fertilizers decreased $(\sim 38$ to $18 \%)$ over the years and that of irrigation increased ( 18 to 59\%). Similarly, in kharif oilseeds the contribution of irrigation increased ( $\sim 7$ to $57 \%)$ and that of fertilizers decreased ( $\sim 76$ to $35 \%)$.

\section{Crop diversification}

Diversification of cropping system can help in reducing the CFP of crops by $32 \%$ to $315 \%$. Gan et al., (2011) (54) reported that in durum wheat, diversification of cropping system with oilseeds and legumes lowered the carbon footprint. Durum wheat grown in a pulsepulse-durum system had carbon footprint $0.27 \mathrm{~kg} \mathrm{CO}_{2} \mathrm{eq} \mathrm{kg}^{-1}$ which is $34 \%$ lower than that of cereal-cereal-durum systems. Yan et al., (2015) (55) showed that early rice had lower carbon footprint values $\left(0.62 \mathrm{t} \mathrm{CO}_{2}\right.$-eqt ${ }^{-}$ 
$\left.{ }^{1}\right)$ than late rice $\left(1.1 \mathrm{t} \mathrm{CO}_{2^{-}} \mathrm{eqt}^{-1}\right)$ system. Indica and japonica rice varieties were compared in Chinese rice fields and japonica varieties were found to have lower CFP $(0.71 \mathrm{t}$ $\left.\mathrm{eqt}^{-1}\right)$ than Indica rice varieties having $1.1 \mathrm{t}$ $\mathrm{CO}_{2}$ eqt $^{-1}$ (Pathak et al., 2002) (56). Pathak et al., (2010) (33) calculated the GWP of different crop production from the data generated from different field experiments conducted at Indian Agricultural Research Institute, New Delhi (Pathak et al., 2003 \& 2009) $(57,58)$ and reported that CFP values of wheat, pulse, oilseed, cauliflower, brinjal, and potato are $0.12,0.31,0.42,0.03,0.03$, and $0.02 \mathrm{~kg} \mathrm{CO}$ eq. $\mathrm{kg}^{-1}$ produce respectively. Leaf colour chart (LCC) based $\mathrm{N}$ application lowered CFP from $0.13 \mathrm{~kg} \mathrm{CO}_{2} \mathrm{eq} \mathrm{kg}^{-1}$ grain to 0.10 and $0.10 \mathrm{~kg} \mathrm{CO}_{2} \mathrm{eq} \mathrm{kg}^{-1}$ grain in rice wheat cropping system in IARI, New Delhi.

Pathak et al., (2003) (57) also found that the effect of both water as well as nitrogen management on GWP of rice-wheat cropping system at IARI, New Delhi. Lower CFP values were observed under intermittent wetting and drying conditions as compared to saturated rice cultivation. This is attributed to the fact that less $\mathrm{CH}_{4}$ emission in IWD condition than saturated one lowered the CFP. Substitution of inorganic $\mathrm{N}$ with organic sources increased $\mathrm{CH}_{4}$ emission resulting in higher CFP whereas application of nitrification inhibitor $(\mathrm{NI})$ caused lower $\mathrm{N}_{2} \mathrm{O}$ emission thereby reducing the CFP values.

\section{Managing tillage practices to reduce carbon footprint}

Tillage disturbance is the dominant factor reducing soil carbon stabilization within micro-aggregates in the clayey soil, whereas conservation practices increase soil organic carbon contents. In some cases, reduced tillage in combination with additional carbon input from cover crops significantly improved the soil organic carbon content (Pinheiro et al., 2015) (59). Plant residue inputs from green manure and the incorporation into the soil by reduced tillage promoted the formation of new aggregates and activated the subsequent physical-chemical protection of organic carbon. Hu et al., (2015) (60) reported that wheat-maize intercropping under reduced tillage with stubble retention increased crop yield by $8 \%$ and reduced greenhouse gas emissions by $7 \%$ compared with conventional tillage. However, soil organic carbon can be gained or lost depending on soil type and land use practices. Soil disturbance affects the quantity and quality of plant residues entering the soil, their seasonal and spatial distribution, and the ratio between above- and belowground inputs (Pinheiro et al., 2015) (59). Data also showed that a linear relationship between carbon input and $\mathrm{CO}_{2}$ output; an increase of $1 \mathrm{Tg}$ $\mathrm{CO}_{2} \mathrm{eq} \mathrm{yr}^{-1}$ of carbon input resulted in a corresponding increase in carbon output of 21 $\mathrm{Tg} \mathrm{CO}_{2}$ eq yr ${ }^{-1}$ (Maheswarappa et al., 2011) (61). Tillage did not influence crop biomass and $\mathrm{CO}_{2}$ flux nor on total soil carbon content (Sainju et al., 2010) (62).

Cropping sequences in a rotation system have significant impacts on the carbon footprint (Gan et al., 2011) (54). In a study of durum wheat had an average carbon footprint of $0.34 \mathrm{~kg} \mathrm{CO}_{2} \mathrm{eq} \mathrm{kg}^{-1}$ of grain when the crop was grown after mustard, which was $19 \%$ lower than when grown after a cereal. Similarly, durum wheat grown after a chickpea, lentil, or dry pea lowered the carbon footprint of durum wheat by $28 \%$ compared with when grown after a cereal. For a 3-year crop rotation, a pulse crop alternatively grown with an oilseed the previous 2 years lowered the carbon footprint of the $3^{\text {rd }}$-year durum wheat crop by an average $25 \%$. When pulse crops were grown continuously for the first 2 years of the 3-year rotation, the carbon footprint of the $3^{\text {rd }}$-year durum crop was lowered by $34 \%$. These results clearly 
demonstrate that the integration of various crop types into a well-designed rotation substantially lowers the carbon footprint of cereal crops.

Table.1 Production of Major Agricultural Crops in India (million tonnes) (Source: Directorate of Economics and Statistics, DAC\&FW (11))

\begin{tabular}{|c|c|c|c|c|c|c|c|c|c|c|c|c|c|}
\hline Crops & $\begin{array}{l}1950- \\
51\end{array}$ & $\begin{array}{l}1960- \\
61\end{array}$ & $\begin{array}{l}1970- \\
71\end{array}$ & $\begin{array}{l}\text { 1980- } \\
81\end{array}$ & 1990-91 & $\begin{array}{l}2000- \\
01\end{array}$ & 2010-11 & 2011-12 & 2012-13 & 2013-14 & 2014-15 & $\begin{array}{l}2015- \\
16\end{array}$ & 2016-17* \\
\hline Food grains & 50.82 & 82.02 & 108.42 & 129.59 & 176.39 & 196.81 & 244.49 & 259.29 & 257.13 & 265.04 & 252.02 & 251.57 & 275.68 \\
\hline Rice & 20.58 & 34.58 & 42.22 & 53.63 & 74.29 & 84.98 & 95.98 & 105.30 & 105.23 & 106.65 & 105.48 & 104.41 & 110.15 \\
\hline Wheat & 6.46 & 11.00 & 23.83 & 36.31 & 55.14 & 69.68 & 86.87 & 94.88 & 93.51 & 95.85 & 86.53 & 92.29 & 98.38 \\
\hline Maize & 1.73 & 4.08 & 7.49 & 6.96 & 8.96 & 12.04 & 21.73 & 21.76 & 22.26 & 24.26 & 24.17 & 22.57 & 26.26 \\
\hline Nutri Cereals & 15.38 & 23.74 & 30.55 & 29.02 & 32.70 & 31.08 & 43.40 & 42.01 & 40.04 & 43.29 & 42.86 & 38.52 & 44.19 \\
\hline Pulses & 8.41 & 12.79 & 11.82 & 10.63 & 14.26 & 11.08 & 18.24 & 17.09 & 18.34 & 19.25 & 17.15 & 16.35 & 22.95 \\
\hline Gram & 3.65 & 6.25 & 5.20 & 4.33 & 5.36 & 3.86 & 8.22 & 7.70 & 8.83 & 9.53 & 7.33 & 7.06 & 9.33 \\
\hline Tur or Arhar & 1.72 & 2.07 & 1.88 & 1.96 & 2.41 & 2.25 & 2.86 & 2.65 & 3.02 & 3.17 & 2.81 & 2.56 & 4.78 \\
\hline $\begin{array}{l}\text { Lentil } \\
\text { (Massur) }\end{array}$ & -- & -- & 0.37 & 0.47 & 0.85 & 0.92 & 0.94 & 1.06 & 1.13 & 1.02 & 1.04 & 0.98 & -- \\
\hline Oilseeds & 5.16 & 6.98 & 9.63 & 9.37 & 18.61 & 18.44 & 32.48 & 29.50 & 30.94 & 32.75 & 27.51 & 25.25 & 32.10 \\
\hline Groundnut & 3.48 & 4.81 & 6.11 & 5.01 & 7.51 & 6.41 & 8.26 & 6.96 & 4.70 & 9.71 & 7.40 & 6.73 & 7.565 \\
\hline $\begin{array}{l}\text { Rapeseed \& } \\
\text { Mustard }\end{array}$ & 0.76 & 1.35 & 1.98 & 2.30 & 5.23 & 4.19 & 8.18 & 6.60 & 8.03 & 7.88 & 6.28 & 6.80 & 7.98 \\
\hline Soy Bean & -- & -- & 0.01 & 0.44 & 2.60 & 5.28 & 12.74 & 12.21 & 14.67 & 11.86 & 10.37 & 8.57 & 13.79 \\
\hline Sunflower & -- & -- & 0.08 & 0.07 & 0.87 & 0.65 & 0.65 & 0.52 & 0.54 & 0.50 & 0.43 & 0.30 & 0.24 \\
\hline Cotton \# & 3.04 & 5.60 & 4.76 & 7.01 & 9.84 & 9.52 & 33.00 & 35.20 & 34.22 & 35.90 & 34.80 & 30.01 & 33.09 \\
\hline $\begin{array}{l}\text { Jute \& Mesta } \\
@\end{array}$ & 3.31 & 5.26 & 6.19 & 8.16 & 9.23 & 10.56 & 10.62 & 11.40 & 10.93 & 11.68 & 11.13 & 10.52 & 10.60 \\
\hline Sugarcane & 57.05 & 110.00 & 126.37 & 154.25 & 241.05 & 295.96 & 342.96 & 361.04 & 341.20 & 352.14 & 362.33 & 348.45 & 306.72 \\
\hline Tobacco & 0.26 & 0.31 & 0.48 & 0.48 & 0.56 & 0.34 & 0.34 & 0.75 & 0.66 & 0.74 & 0.84 & 0.80 & -- \\
\hline
\end{tabular}

(Source: Directorate of Economics and Statistics, DAC\&FW)

Table.2 All India crop-wise yield (quintal/ha)

\begin{tabular}{|c|c|c|c|c|c|c|c|c|c|c|}
\hline Crops & $1950-51$ & 1990-91 & 2000-01 & 2010-11 & 2011-12 & 2012-13 & 2013-14 & 2014-15 & 2015-16 & 2016-17* \\
\hline Rice & 6.68 & 17.40 & 19.01 & 22.39 & 23.93 & 24.61 & 24.16 & 23.91 & 24.00 & 25.50 \\
\hline Jowar & 3.53 & 8.14 & 7.64 & 9.49 & 9.57 & 8.50 & 9.57 & 8.85 & 6.97 & 8.89 \\
\hline Bajra & 2.88 & 6.58 & 6.88 & 10.79 & 11.71 & 11.98 & 11.84 & 12.54 & 11.32 & 13.11 \\
\hline Maize & 5.47 & 15.18 & 18.22 & 25.40 & 24.78 & 25.66 & 26.76 & 26.30 & 25.63 & 26.64 \\
\hline Wheat & 6.63 & 22.81 & 27.08 & 29.88 & 31.77 & 31.17 & 31.45 & 27.50 & 30.34 & 32.16 \\
\hline Nutri Cereals & 4.08 & 9.00 & 10.27 & 15.31 & 15.90 & 16.17 & 17.17 & 17.03 & 15.79 & 17.84 \\
\hline Gram & 4.82 & 7.12 & 7.44 & 8.95 & 9.28 & 10.36 & 9.60 & 8.88 & 8.40 & 9.73 \\
\hline Tur or Arhar & 7.88 & 6.73 & 6.18 & 6.55 & 6.62 & 7.76 & 8.13 & 7.30 & 6.46 & 8.85 \\
\hline Total Pulses & 4.41 & 5.78 & 5.44 & 6.91 & 6.99 & 7.89 & 7.64 & 7.28 & 6.56 & 7.79 \\
\hline Total Foodgrains & 5.22 & 13.80 & 16.26 & 19.30 & 20.78 & 21.29 & 21.20 & 20.28 & 20.42 & 21.53 \\
\hline Sugarcane & 334.22 & 653.95 & 685.78 & 700.91 & 703.17 & 682.54 & 705.22 & 715.12 & 707.22 & 698.86 \\
\hline Groundnut & 7.75 & 9.04 & 9.77 & 14.11 & 13.05 & 9.95 & 17.64 & 15.52 & 14.65 & 14.24 \\
\hline Mustard & 3.68 & 9.04 & 9.36 & 11.85 & 11.45 & 12.62 & 11.85 & 10.83 & 11.83 & 13.24 \\
\hline Soy Bean & 4.26 & 10.15 & 8.23 & 13.27 & 12.07 & 13.53 & 10.12 & 9.51 & 7.38 & 12.19 \\
\hline Sunflower & 6.53 & 5.35 & 6.05 & 7.01 & 6.92 & 6.55 & 7.50 & 7.36 & 6.08 & 6.99 \\
\hline Total oilseeds & 4.81 & 7.71 & 8.10 & 11.93 & 11.35 & 11.68 & 11.68 & 10.75 & 9.68 & 12.25 \\
\hline Cotton & 0.88 & 2.25 & 1.90 & 4.99 & 4.91 & 4.86 & 5.10 & 4.62 & 4.15 & 5.19 \\
\hline Tobacco & 7.31 & 13.53 & 13.18 & 16.37 & 16.13 & 15.42 & 16.12 & 18.42 & 17.81 & NA \\
\hline
\end{tabular}

(Source: Directorate of Economics and Statistics, DAC\&FW) 
Table.3 World, Asian, and Indian trends in greenhouse gas emissions from various agricultural activities, as a percentage of the total (Source: FAO. 2016 (22))

\begin{tabular}{|l|l|l|l|l|l|l|l|l|l|l|l|l|l|}
\hline \multirow{2}{*}{ Period } & \multicolumn{3}{|c|}{ Enteric emissions } & \multicolumn{3}{|c|}{ Manure left on pastures } & \multicolumn{3}{c|}{ Manure management } & \multicolumn{3}{c|}{ Manure applied } \\
\cline { 2 - 14 } & World & Asia & India & World & Asia & India & World & Asia & India & World & Asia & India \\
\hline $\mathbf{1 9 8 0}$ & 45.4 & 35 & 50.8 & 15.6 & 10.9 & 10.8 & 8.3 & 6.6 & 5.0 & 4.4 & 3 \\
\hline $\mathbf{1 9 8 1 - 1 9 9 0}$ & 41.1 & 33.9 & 50 & 14.2 & 10.5 & 10.8 & 7.5 & 6.4 & 4.9 & 4 & 3 \\
\hline $\mathbf{1 9 9 1 - 2 0 0 0}$ & 40.3 & 33.7 & 47.8 & 14.9 & 10.9 & 10.5 & 7.1 & 6.6 & 4.8 & 3.8 & 3.3 & 2.5 \\
\hline $\mathbf{2 0 0 1 - 2 0 0 5}$ & 40.1 & 34 & 47.4 & 15.3 & 11.4 & 10.6 & 6.8 & 6.9 & 4.8 & 3.6 & 3.5 & 2.5 \\
\hline $\mathbf{2 0 0 6 - 2 0 1 0}$ & 40.3 & 34.3 & 46.2 & 16 & 11.6 & 10.5 & 6.8 & 7 & 4.6 & 3.7 & 3.6 & 2.5 \\
\hline $\mathbf{2 0 1 1}$ & 39.3 & 34.1 & 45 & 15.7 & 11.5 & 10.3 & 6.6 & 7 & 4.5 & 3.6 & 3.6 & 2.4 \\
\hline $\mathbf{2 0 1 2}$ & 39.4 & 34.1 & 45.4 & 15.9 & 11.7 & 10.4 & 6.6 & 7 & 4.5 & 3.6 & 3.7 & 2.4 \\
\hline $\mathbf{2 0 1 3}$ & 39.9 & 34.1 & 45.3 & 16.2 & 11.7 & 10.3 & 6.7 & 7 & 4.5 & 3.7 & 3.7 & 2.4 \\
\hline $\mathbf{2 0 1 4}$ & 39.7 & 34.3 & 45.2 & 16.1 & 11.8 & 10.3 & 6.7 & 7 & 4.5 & 3.7 & 3.7 & 2.4 \\
\hline
\end{tabular}

\begin{tabular}{|l|l|l|l|l|l|l|l|l|l|l|l|l|l|}
\hline \multirow{2}{*}{ Period } & \multicolumn{3}{|c|}{ Rice cultivation } & \multicolumn{3}{c|}{ Synthetic fertilizer } & \multicolumn{3}{c|}{$\begin{array}{c}\text { Burning crop residue } \\
\text { and savanna }\end{array}$} & \multicolumn{3}{c|}{ Crop residue } \\
\cline { 2 - 6 } & World & Asia & India & World & Asia & India & World & Asia & India & World & Asia & India \\
\hline $\mathbf{1 9 8 0}$ & 11.9 & 29.7 & 21.1 & 10.2 & 10.1 & 5.6 & 0.6 & 8 & 0.7 & 3.4 & 4 & 3.4 \\
\hline $\mathbf{1 9 8 1 - 1 9 9 0}$ & 10.4 & 26 & 19.4 & 10.4 & 12 & 8 & 6.2 & 2.7 & 0.7 & 3.2 & 4 & 3.5 \\
\hline $\mathbf{1 9 9 1 - 2 0 0 0}$ & 10.4 & 22.7 & 18 & 11.1 & 15 & 12 & 6.0 & 1.1 & 0.6 & 3.4 & 4 & 3.6 \\
\hline $\mathbf{2 0 0 1 - 2 0 0 5}$ & 10.1 & 21.4 & 17 & 11.3 & 15.2 & 13.2 & 6.0 & 1 & 0.6 & 3.5 & 3.9 & 3.7 \\
\hline $\mathbf{2 0 0 6 - 2 0 1 0}$ & 10.1 & 20.5 & 15.8 & 11.8 & 15.7 & 15.9 & 5.1 & 0.9 & 0.6 & 3.7 & 4 & 3.7 \\
\hline $\mathbf{2 0 1 1}$ & 10 & 20.4 & 15.4 & 12.2 & 16.1 & 17.7 & 6.1 & 0.8 & 0.6 & 3.8 & 4.2 & 3.9 \\
\hline $\mathbf{2 0 1 2}$ & 10 & 20.2 & 15.1 & 12.4 & 16 & 17.4 & 5.9 & 0.9 & 0.7 & 3.7 & 4.2 & 4 \\
\hline $\mathbf{2 0 1 3}$ & 10.1 & 20.4 & 15.5 & 12.5 & 15.9 & 17.2 & 4.5 & 0.7 & 0.6 & 4 & 4.2 & 4 \\
\hline $\mathbf{2 0 1 4}$ & 10 & 20 & 15.3 & 12.6 & 15.8 & 17.4 & 4.7 & 0.9 & 0.6 & 4 & 4.2 & 3.9 \\
\hline
\end{tabular}

Table.4 Sector wise annual carbon emission and sequestration (Source: Ramachandra and Shwetmala, 2012)

\begin{tabular}{|l|l|l|l|l|}
\hline Carbon sources & $\mathbf{C O}_{\mathbf{2}}(\mathbf{G g})$ & $\mathbf{C O}(\mathbf{G g})$ & $\mathbf{C H}_{\mathbf{4}}(\mathbf{G g})$ & $\begin{array}{l}\text { Total } \\
\text { emission } \mathbf{( G g})\end{array}$ \\
\hline Agriculture & 85851.0 & 3459.2 & 15246.9 & 409495.88 \\
\hline Domestic & 88378.5 & 14798.7 & 611.5 & 116018.91 \\
\hline Electricity & 343344.5 & 1237.3 & 0.0 & 344581.81 \\
\hline $\begin{array}{l}\text { Steel and cement } \\
\text { industries }\end{array}$ & 202190.0 & 0.0 & 0.0 & 202190.02 \\
\hline Transport & & & & \\
\hline Waste & 246232.4 & 3030.9 & 127.3 & 251936.79 \\
\hline Total $(\mathbf{G g})$ & 0.0 & 0.0 & 995.72 & 21104.79 \\
\hline Carbon sinks & 965996.5 & 22526.0 & 16990.8 & 1345328.2 \\
\hline Forest biomass & & & & Carbon stored $(\mathbf{G g})$ \\
\hline Forest soil & & & & 72916.77 \\
\hline Agricultural soil & & & & 20312.64 \\
\hline Total $(\mathbf{G g})$ & & & & 5600.49 \\
\hline Net emission & & & & 1246498.3 \\
\hline
\end{tabular}


Table.5 Seasonal evapotranspiration (ET) and percolation $(\mathrm{mm})$ in principal field crops grown in Indian Punjab (Adapted from Arora et al., 2008)

\begin{tabular}{|c|c|c|c|}
\hline Crop & ET & Percolation & Total \\
\hline Rice & 650 & 1400 & 2050 \\
\hline Maize & 480 & 270 & 750 \\
\hline Cotton & 600 & 150 & 750 \\
\hline Wheat & 380 & 80 & 460 \\
\hline Pulses & 320 & 40 & 360 \\
\hline Oilseeds & 280 & 40 & 320 \\
\hline Sugarcane & 1350 & 200 & 1550 \\
\hline
\end{tabular}

Table.6 Carbon equivalent cost of various field operations in different crops (Source: Benbi, 2019)

\begin{tabular}{|l|l|l|l|l|}
\hline Crop & \multicolumn{2}{|l|}{ Field preparation } & \multicolumn{2}{l|}{ Seeding, harvesting and threshing } \\
\hline Operation & $\begin{array}{l}\text { CE kg ha } \\
\text { Risking (1), cultivator (2), } \\
\text { Malverization (1) }\end{array}$ & 25.2 & Combine harvester & CE kg ha-1 \\
\hline Wheat & $\begin{array}{l}\text { Disking (1), cultivator (2), } \\
\text { planking (1) }\end{array}$ & 16.9 & $\begin{array}{l}\text { Seed- cum fertilizer drill Thresher\# } \\
\text { or } \\
\text { Straw combine }\end{array}$ & $\begin{array}{l}6.1 \\
24.7 \\
18.6\end{array}$ \\
\hline Maize & $\begin{array}{l}\text { Disking (1), cultivator (2), } \\
\text { planking (1) }\end{array}$ & 23.0 & Dehusking \& shelling & 18.2 \\
\hline Cotton & $\begin{array}{l}\text { Disking(1), cultivator (2), } \\
\text { planking (1) }\end{array}$ & 23.0 & Manual & 0 \\
\hline Pulses & $\begin{array}{l}\text { Cultivator (2), planking (1) } \\
\text { Cultivator (2), planking (1) }\end{array}$ & 15.9 & Manual & 0 \\
\hline Groundnut & $\begin{array}{l}\text { Disking(1), cultivator (3), } \\
\text { planking (3) }\end{array}$ & Mechanical & 14.9 \\
\hline Oilseeds & $\begin{array}{l}\text { Cultivation (5) } \\
\text { Sugarcane }\end{array}$ & 30.1 & Manual & 0 \\
\hline Planter & 24.1 \\
\hline
\end{tabular}

\#in 1980-81 and 1990-91; * 2000-01 onwards

Table 7: Straw: economic yield and shoot: root ratio for different crops (Source: Benbi, 2019 (27))

\begin{tabular}{|l|c|c|c|l|}
\hline Crop & $\begin{array}{c}\text { Straw : economic } \\
\text { yield ratio }\end{array}$ & Harvest index (HI) & Shoot/Root & Reference \\
\hline Rice & $1.88^{*}$ & 0.348 & 6.25 & Author's unpublished \\
\hline Wheat & 1.5 & 0.40 & 7.14 & Anonymous (1991) \\
\hline Maize & 2 & 0.333 & 6.67 & Author's unpublished \\
\hline Cotton & 1.6 & 0.384 & 6.25 & Pace et al., 1999 \\
\hline Oilseeds & 2 & 0.33 & 9.09 & Arora et al., (1993) \\
\hline Sugarcane & 0.35 & 0.74 & 5.88 & Smith et al., $(2005)$ \\
\hline
\end{tabular}

*Includes conversion of paddy to rice ( $2 / 3{ }^{\text {rd }}$ of paddy equals rice grain yield) 
Table 8: Agro-climatic, zone-based bagasse potential for existing and future co-generation capacity in Uttar Pradesh, India.

\begin{tabular}{|c|c|c|c|c|c|c|c|c|}
\hline $\begin{array}{l}\text { Agro-climatic } \\
\text { Zone }\end{array}$ & District & $\begin{array}{c}\text { Sugar } \\
\text { mills }\end{array}$ & $\begin{array}{c}\text { Co- } \\
\text { generation } \\
\text { plants* }\end{array}$ & $\begin{array}{c}\text { Surplus } \\
\text { bagasse } \\
\text { production, } k t^{\mathrm{b}}\end{array}$ & $\begin{array}{l}\text { Existing } \\
\text { capacity, } \\
M W^{*}\end{array}$ & $\begin{array}{c}\text { Potential } \\
, M W^{b}\end{array}$ & $\begin{array}{l}\text { Scope of additional } \\
\text { generation } M W^{h}\end{array}$ & Remarks \\
\hline $\begin{array}{l}\text { Bhabar and } \\
\text { Terai(ACZ1) }\end{array}$ & 3 & 17 & 9 & 3.864 & 194 & 276 & $\begin{array}{c}82.00 \\
(718,320 \mathrm{MWh})\end{array}$ & $\begin{array}{l}\text { Largest existing and future potential of } \\
141 \text { and } 202 \mathrm{MW} \text { in Bijnor district. }\end{array}$ \\
\hline $\begin{array}{l}\text { Bundelkhand } \\
\text { (ACZ2) }\end{array}$ & 7 & 3 & 0 & 825.09 & 0 & 5.89 & $\begin{array}{c}5.89 \\
(51,596.4 \mathrm{MWh})\end{array}$ & $\begin{array}{l}\text { Largest future potential of } 1.86 \mathrm{MW} \text { in } \\
\text { Mahoba district. }\end{array}$ \\
\hline $\begin{array}{l}\text { Central } \\
(\text { ACZ3) }\end{array}$ & 16 & 11 & 6 & $2,131.35$ & 90 & 152 & $\begin{array}{c}62.00 \\
(51,596.4 \mathrm{MWh})\end{array}$ & $\begin{array}{l}\text { Largest existing and future potential of } 60 \\
\text { and } 101 \mathrm{MW} \text { in Sitapur district. }\end{array}$ \\
\hline $\begin{array}{l}\text { Eastern plain } \\
(\mathrm{ACZ4})\end{array}$ & 11 & 9 & 4 & $1,186.92$ & 67.95 & 85 & $\begin{array}{c}17.05 \\
(149,358 \mathrm{MWh})\end{array}$ & $\begin{array}{l}\text { Largest existing and future potential of } 18 \\
\text { and } 36 \mathrm{MW} \text { in Ayodhya district. }\end{array}$ \\
\hline $\begin{array}{l}\text { Midwestern } \\
\text { plain(ACZ5) }\end{array}$ & 5 & 19 & 5 & $3,751.19$ & 141.5 & 268 & $\begin{array}{c}126.50 \\
(1,108.140 \mathrm{MWh})\end{array}$ & $\begin{array}{l}\text { Largest existing capacity in Mordabad ( } 40 \\
\text { MW) and highest future potential in } \\
\text { baireilly district ( } 71 \mathrm{MW}) \text {. }\end{array}$ \\
\hline $\begin{array}{l}\text { North eastern } \\
\text { plain(ACZ6) }\end{array}$ & 12 & 34 & 13 & 6545 & 215 & 467 & $\begin{array}{c}252.00 \\
(2,207.520 \mathrm{MWh})\end{array}$ & $\begin{array}{l}\text { Largest existing and future potential of } 79 \\
\text { and } 214 \mathrm{MW} \text { in Lakhimpur-Kheri district, } \\
\text { respectively. }\end{array}$ \\
\hline $\begin{array}{l}\text { South } \\
\text { western(ACZ7) }\end{array}$ & 8 & 4 & 0 & 278.29 & 0 & 20 & $\begin{array}{c}20.00 \\
(175.200 \mathrm{MWh})\end{array}$ & $\begin{array}{l}\text { Largest future potential of } 8 \mathrm{MW} \text { in } \\
\text { Aligarh district. }\end{array}$ \\
\hline $\begin{array}{l}\text { Vindhyan } \\
\text { (ACZ8) }\end{array}$ & 3 & 1 & 0 & 34.42 & 0 & 2.46 & $\begin{array}{c}2.46 \\
(21.549 .6 \mathrm{MWh})\end{array}$ & $\begin{array}{l}\text { Largest future potential of } 1.41 \mathrm{MW} \text { in } \\
\text { Mirzapur district. }\end{array}$ \\
\hline $\begin{array}{l}\text { Western plain } \\
\text { (ACZ9) }\end{array}$ & 7 & 35 & 16 & 9178.2 & 252.66 & 655 & $\begin{array}{c}402.34 \\
(3,524,498.4 \mathrm{MWh})\end{array}$ & $\begin{array}{l}\text { Largest existing and future potential of } \\
140 \text { and } 232 \mathrm{MW} \text { in Muzaffarnagar } \\
\text { district, respectively. }\end{array}$ \\
\hline Uttar Pradesh & 72 & 133 & 53 & $27,794.46$ & 961.11 & 1931.35 & $\begin{array}{c}970.24 \\
(8,499,302.4 \mathrm{MWh})\end{array}$ & \\
\hline
\end{tabular}

(Source: Indian Sugar Mills Association, 2016) (49).

Table 9: Key statistics on sugarcane bagasse and bagasse-based bioelectricity potential for Uttar Pradesh, India

\begin{tabular}{|c|c|c|c|}
\hline Parameter & State total & State average & Remarks \\
\hline Total sugarcane area, ha & $2,162,400$ & 30,032 & Largest in Boijnor district((233.300 ha) \\
\hline Sugarcane production, kty $^{-1}$ & 128.819 & 1,790 & Largest in Muzaffanagar district(15,465 kilo tonne) \\
\hline Sugarcane productivity, $\mathrm{t}$ ha $^{-1}$ & - & 55.44 & Largest in Bagpat district $\left(67,68 \mathrm{tha}^{-1}\right)$ \\
\hline Gross bagasse production, kty $^{-1}$ & 38,646 & 537 & Largest gross and net bagasse \\
\hline Net bagasse production, kty $^{-1}$ & 27,052 & 376 & Production of 4,639.5 kt and 3,247.6 respectively \\
\hline Bioelectricity generation potential, $\mathrm{MW}$ & $1,931.35$ & 26.81 & Largest of $232 \mathrm{MW}$ potential in Muzaffarnagar district \\
\hline Per unit area bioelectricity potential, $\mathrm{KW} \mathrm{km} \mathbf{~}^{2}$ & - & 7.99 & Largest of $57.81 \mathrm{kw} \mathrm{km}^{-2}$ in muzaffarnagar district. \\
\hline $\begin{array}{l}\text { Per capita bioelectricity potential, kWh per } \\
\text { capita }\end{array}$ & - & 76.00 & Largest of 500.44 kwh per capita in bagpat district. \\
\hline
\end{tabular}

(Source: Geographical area, population data, sugarcane area, productivity data were collected from the Census of India, 2011 and DoES, 2016). 
Fig.1(A) Agro-climatic zones of U.P

Fig.1(B) Agro-ecological Regions map of India (Source: ICAR-NBSS\&LUP Technologies. 2016)

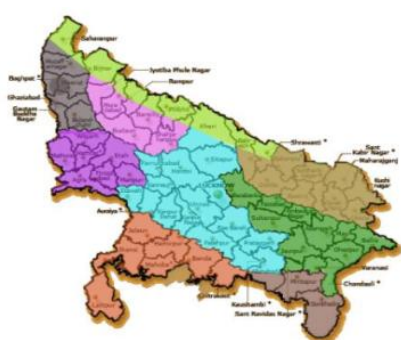

(A)

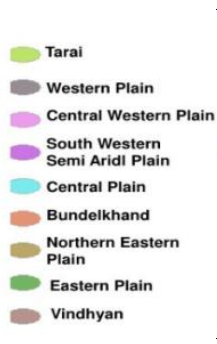

Vindhyan

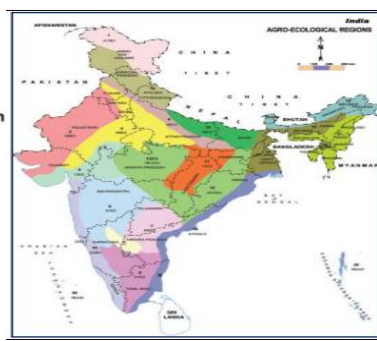

(a) 1992

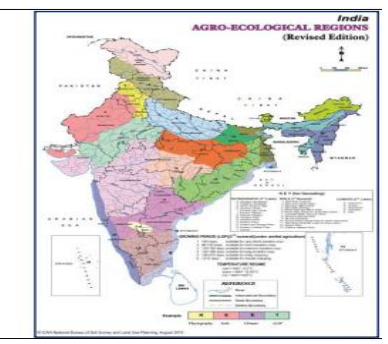

(b) 2015

(B)

Map showing (a) spatial distribution of long-term average annual accumulated growing degree days (AGDD); (b) temporal trends in annual accumulated growing degree days during the period 1900-2014 of U.P
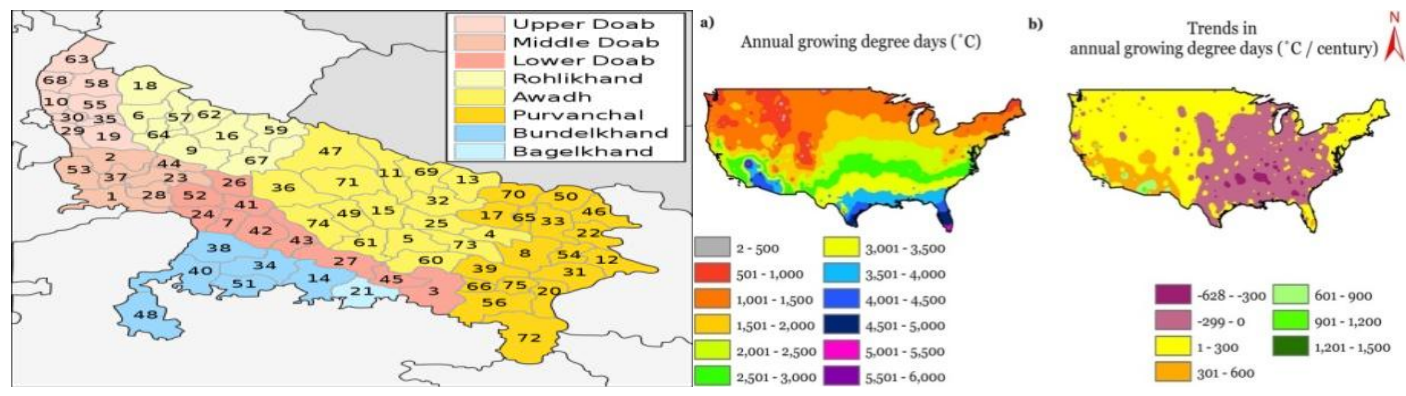

Fig.2 (a): GHG emission sources/removals and processes in managed ecosystems (Source: IPCC, 2006).

Fig.2 (b): Trend for economy wide emissions (2005 to 13) from India.(Source: GHG PlatformIndia, 2017).

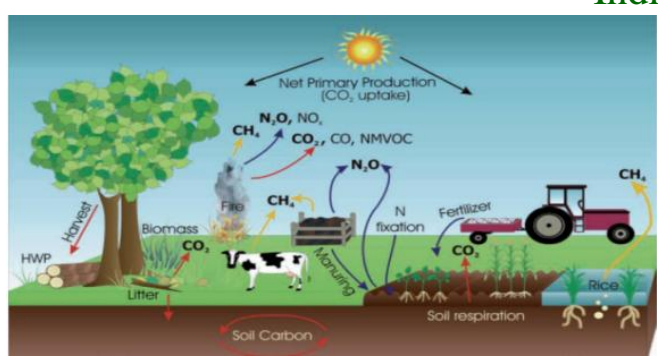

(a)

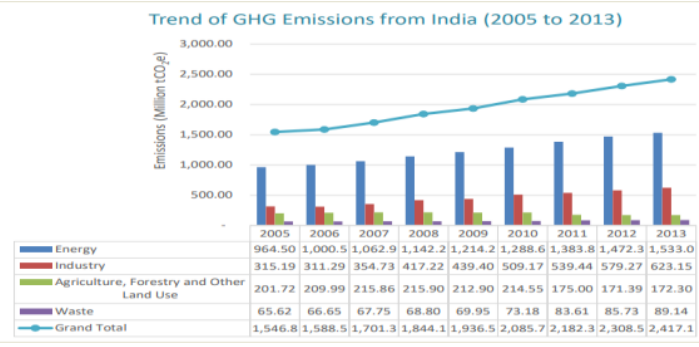

(b) 
Fig.3 Sector wise contribution in total Carbon emission $\left(\mathrm{CO}_{2}=987.1 \mathrm{Tg} /\right.$ year, $\mathrm{CO}=24.7$ $\mathrm{Tg} /$ year, $\mathrm{CH}_{4}=17.0 \mathrm{Tg} /$ year) of India (Source: Ramachandra and Shwetmala, 2012).
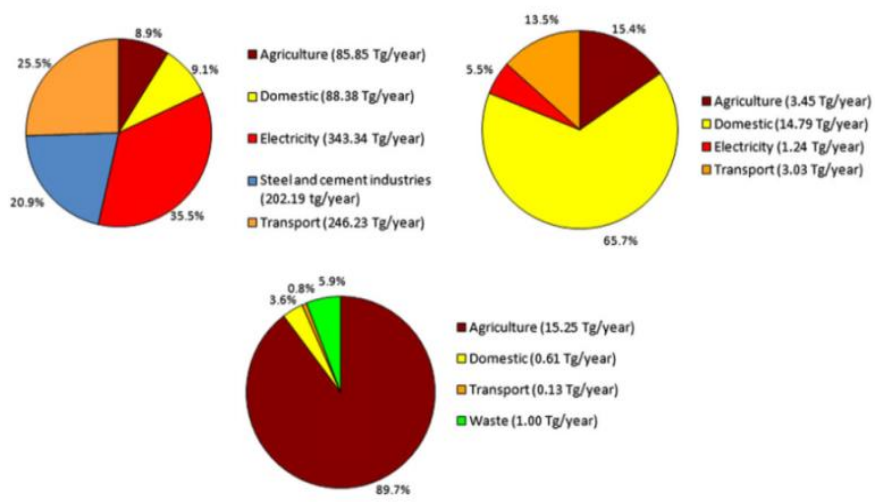

Fig.4 a) Trends in greenhouse gas emission from Indian agriculture and b) from different sources during 1970-2010 (Pathak et al., 2010).

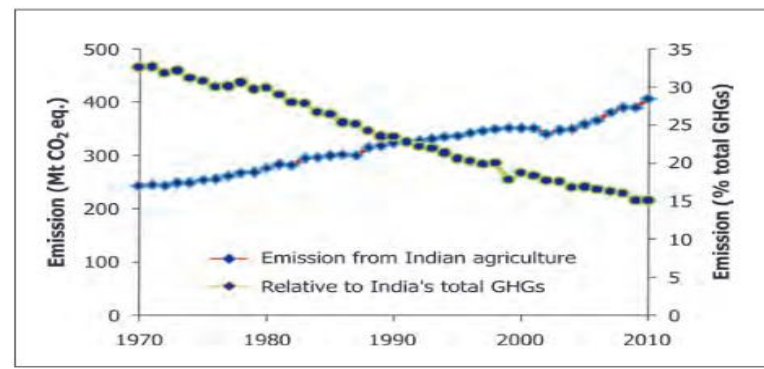

(a)

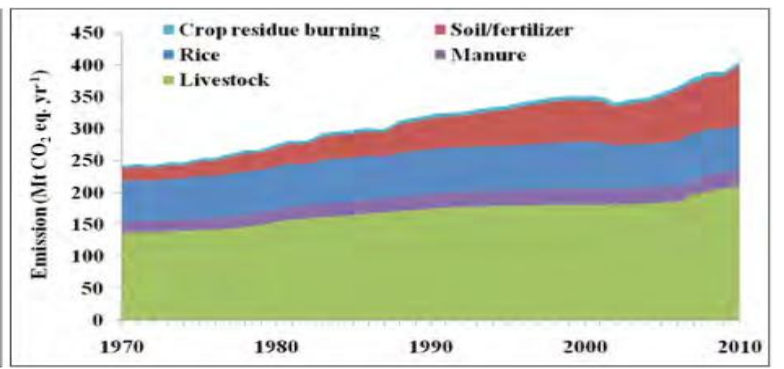

(b)

Fig.5(a) Spatial distribution of GHG mitigation potential $\left(\mathrm{MtCO}_{2} \mathrm{e}\right.$ per year) through improved fertilizer management in India (Source: Sapkota et al., 2019).

Fig.5(b) Trends of production data in major chemicals (Source: Annual report 2018-2019 Govt. of India Ministry of Chemicals \& Fertilizers).
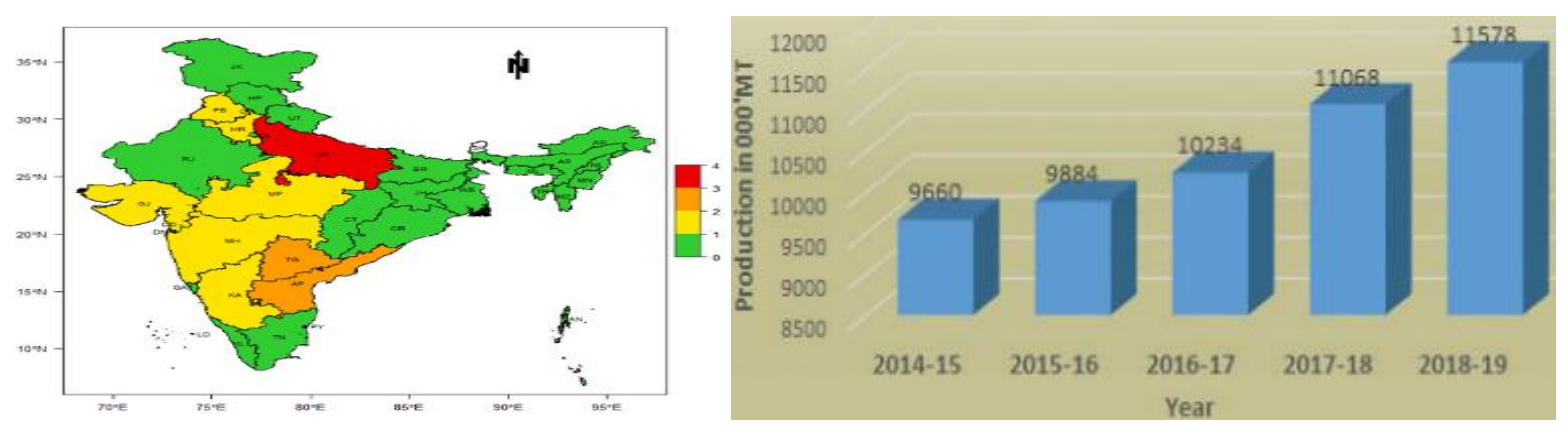
Fig.6 a) Consumption of $\mathrm{N}$ fertilizers b) GHG emissions from the manufacture of nationally produced synthetic $\mathrm{N}$ fertilizers and from $\mathbf{C}$ ) synthetic $\mathrm{N}$ application to soils in India from 196061 to 2006-07 (Source: Fertiliser Association of India (FAI, 2007); Tirado et al., 2010).

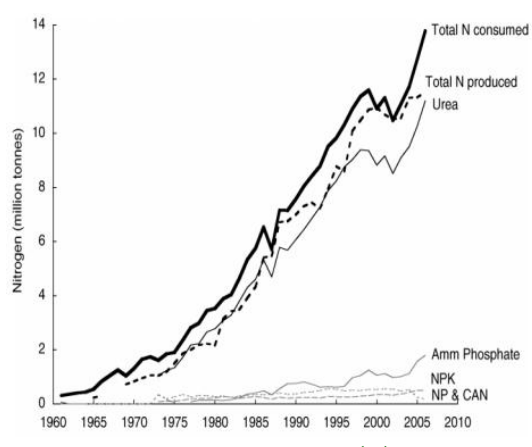

(a)

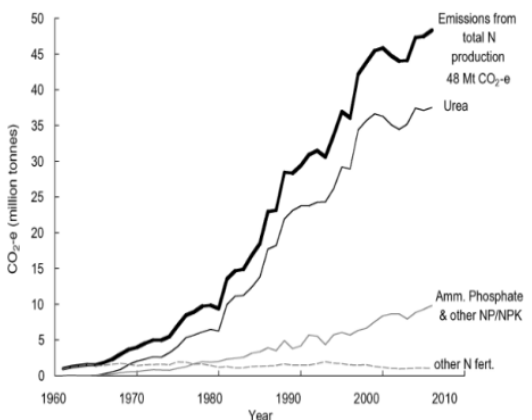

(b)

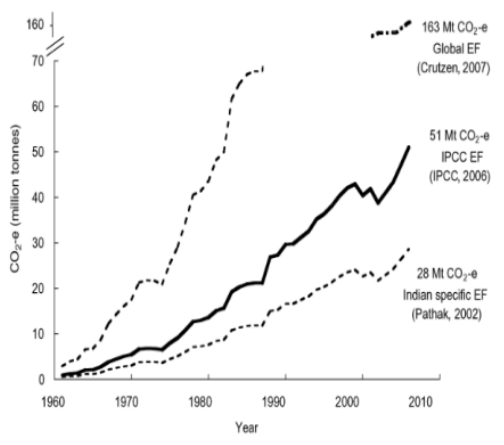

(c)

Fig.7 (a): Groundwater pumping in India change in the net irrigated area from different sources (Source: Mishra et al., 2018)

Fig.7(b): Irrigation based CE emissions in different crops
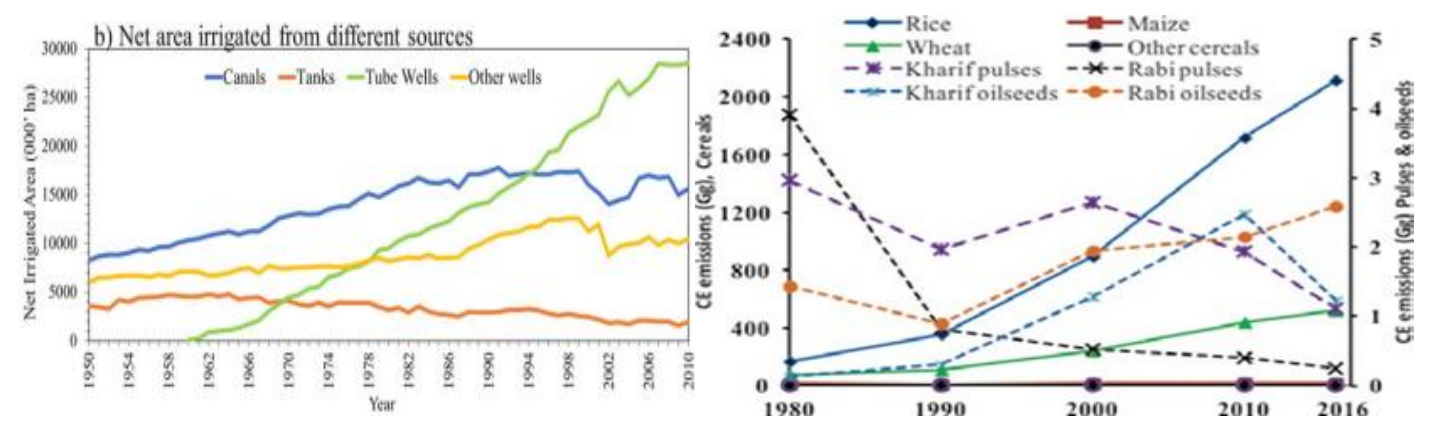

Fig.8 (a): The trend of crop residue generation in India. (Source: Ministry of Statistics and Program Implementation (MOSPI, 2013-14)

Fig.8 (b): The trend of crop residue generation in India. (Source: Ministry of Statistics and Program Implementation (MOSPI, 2013-14)

Fig.8 (c): State-wise distribution of crop residues burnt in India (Jain et al., 2014)
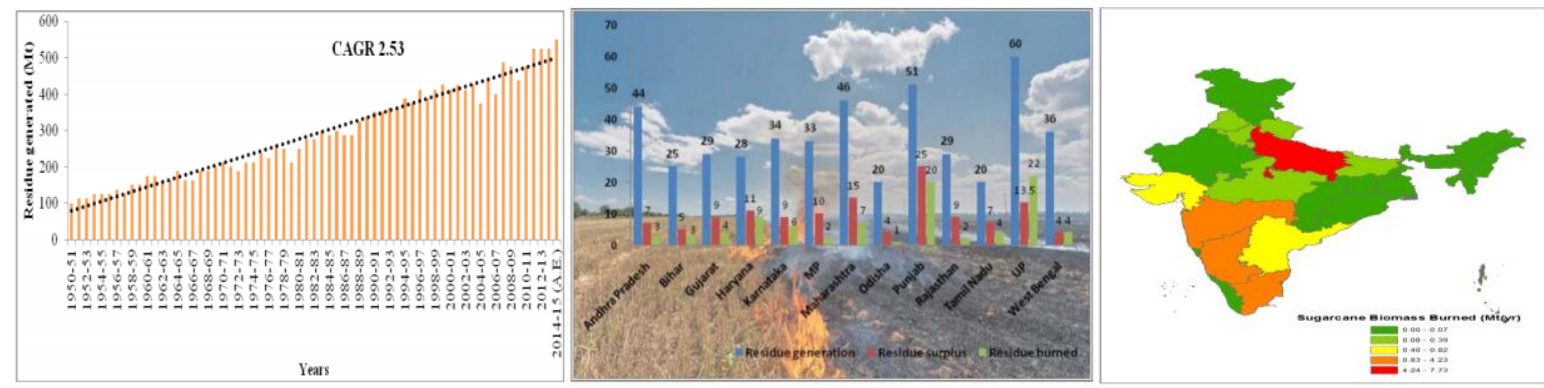
Fig.9: a) Methane production, oxidation, and emission from rice paddy field and (b) $\mathrm{N}_{2} \mathrm{O}, \mathrm{NO}$, and $\mathrm{N}_{2}$ emissions from rice paddy field. (Source: Ali et al., 2019)

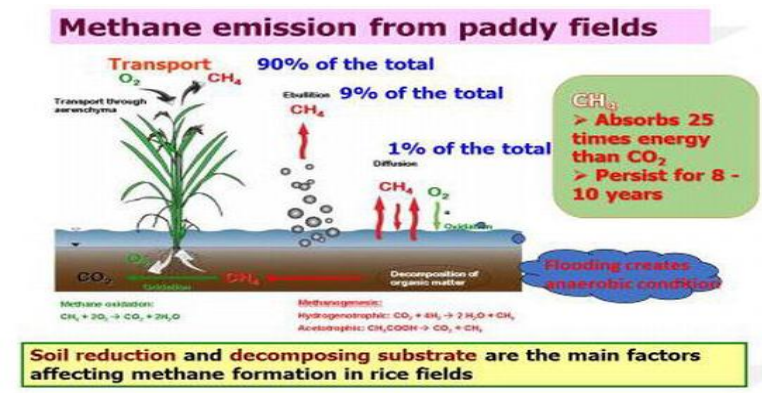

(a)

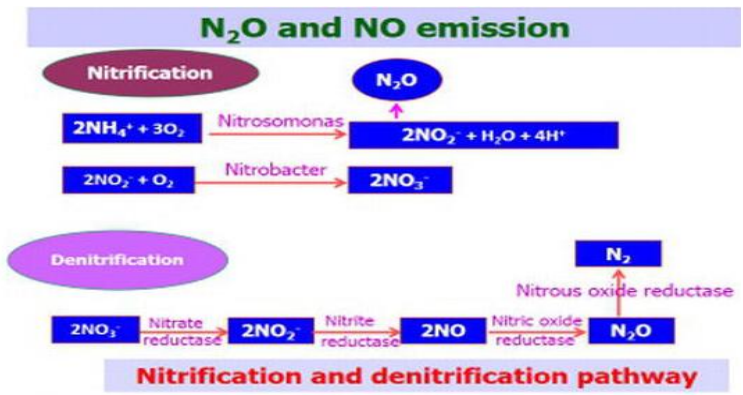

(b)

Fig.10 Methane emissions from Indian paddy fields from 1979 to 2006 . (i) Variability in methane emissions, (ii) variability in cumulative methane emissions from Indian paddy water regimes. (iii) Variability in cumulative methane emissions from Indian states' paddy water regimes. (Source: Gupta et al., 2009)
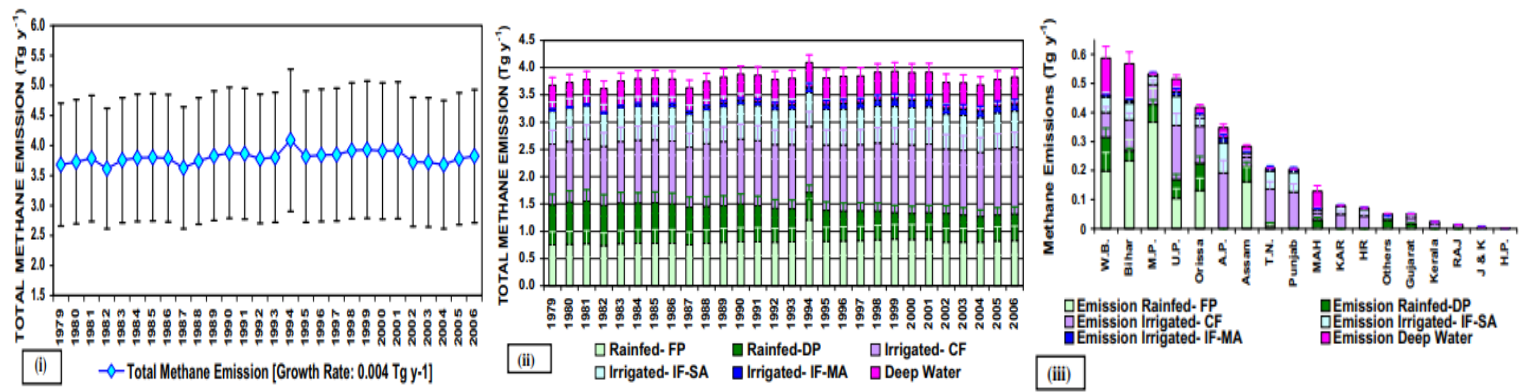

Fig.11(a): Estimates of methane emission from Indian rice fields over the years. IARI 1994, 2000, 2007 and 2010

Fig.11(b): Estimates of nitrous oxide emission from Indian agricultural soils. IARI 2000, 2007 and 2010 (Source: Pathak et al., 2014)

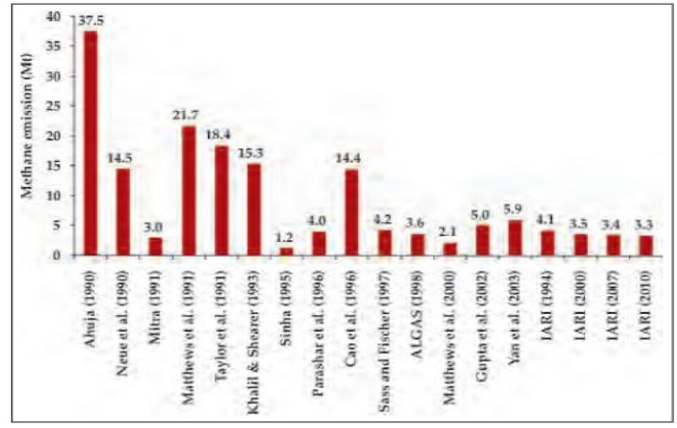

(a)

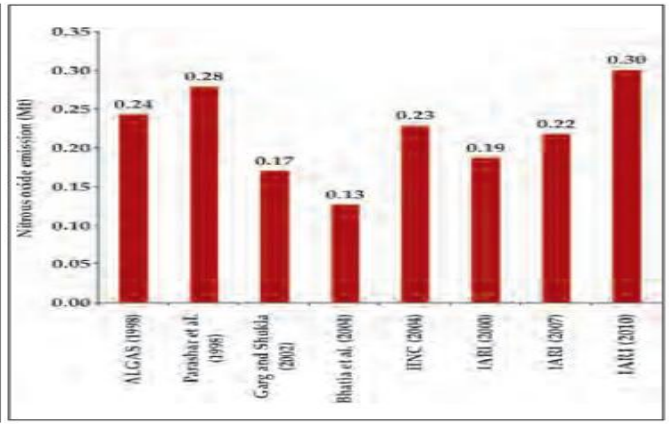

(b) 
Fig.12 Time series of various variables e.g. maize production, rainfall and tropospheric $\mathrm{NO}_{2}$ over 5 sites (Saharanpur, Muzaffarnagar, Meerut, Ghaziabad, and Mathura) from Uttar Pradesh during summer (a) Maize production; (b) Rainfall anomalies;(c) Total tropospheric $\mathrm{NO}_{2}$ (Source:

Kumar et al., 2018)

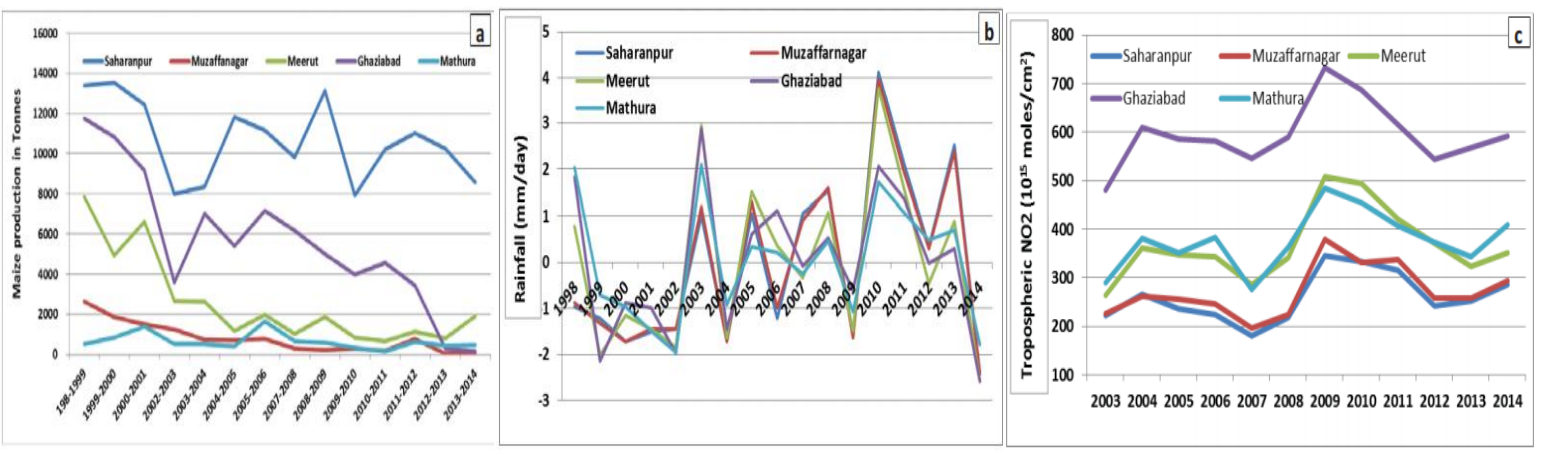

Fig.13 (a): Effect of elevated carbon dioxide concentration on sugarcane crop.

Fig.13(b): State-of-the-art of sugarcane production and per cent recovery in India and Uttar Pradesh (Source: Cooperative Sugar, 2014)
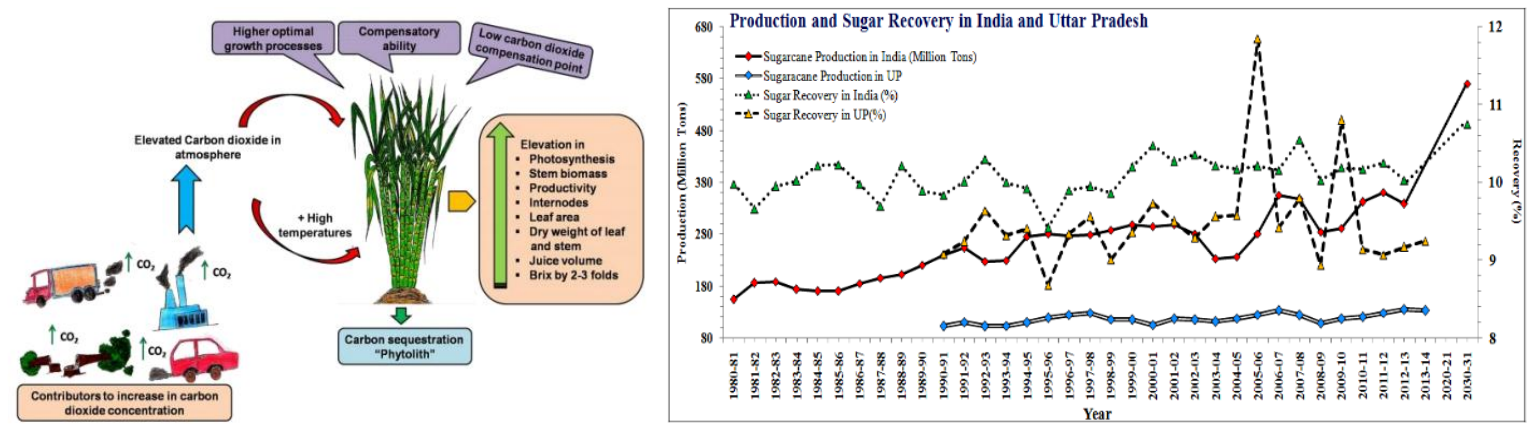

Fig.14 Comparison of land and water productivity of rice (a) and sugarcane (b) across major producing states (Source: Sharma et al., 2018)

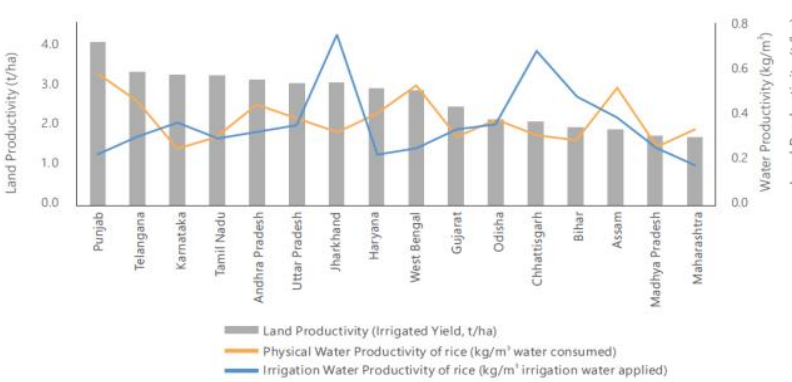

(a)

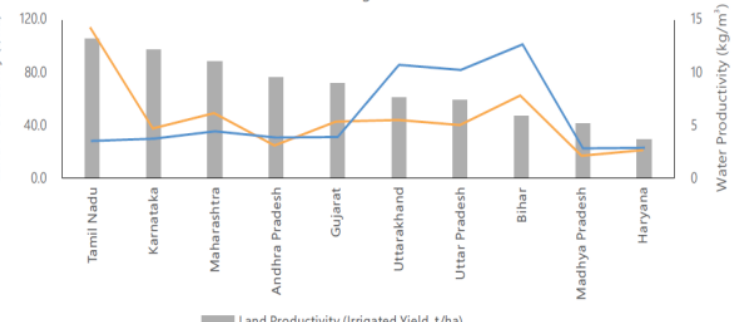

Le Land Productivity (Irigated Yield, tha) — Physical Water Productivity $(\mathrm{kg} / \mathrm{m})$

(b) 
Fig.15 Irrigation based EC emissions in different crops in U.P. during 1980-81 to 2015-16
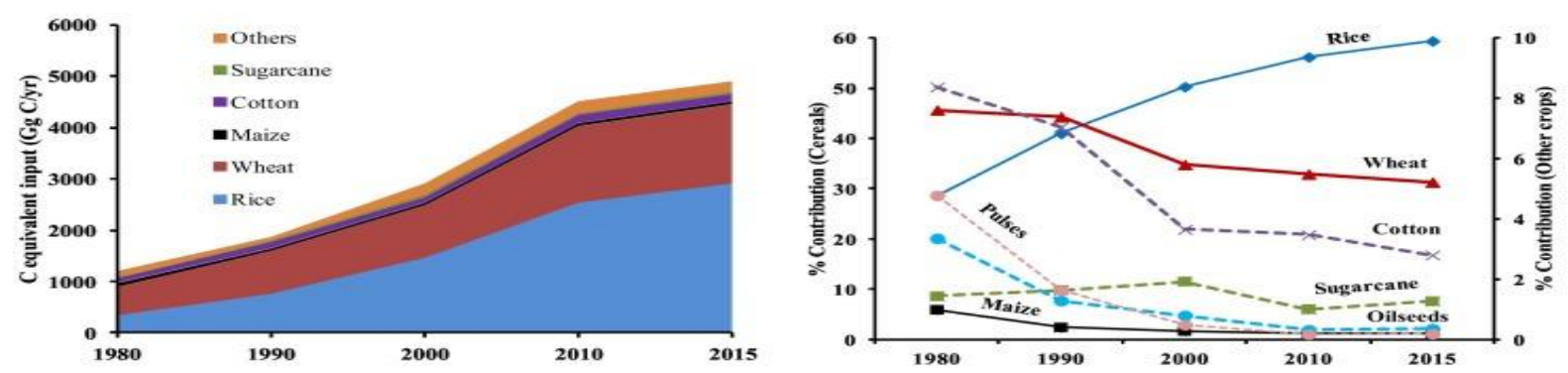

Hence concluded that sustainable agricultural systems are needed to produce high-quality and affordable food in sufficient quantity to meet the growing population need for food, feed, and fuel, and, at the same time, farming systems must have a low impact on the environment. The challenge of meeting food demand while lowering the environmental footprints can be alleviated by adopting various improved agronomical practices. The key agronomical tactics include, but are not limited to diversification of cropping systems, improvement of $\mathrm{N}$ fertilizer use efficiency, adoption of intensified rotation with reduced summer fallow, enhancement of carbon conversion from atmospheric $\mathrm{CO}_{2}$ into plant biomass and ultimately sequestered into the soil, use of reduced tillage in combination with crop residue retention; integration of key cropping practices systematically, and inclusion of $\mathrm{N}_{2}$-fixing pulses in crop rotations. This review signifies the importance of assessment of CFP of rice-wheat cropping system for reducing GHG emission while maintaining productivity of the system. In recent times adoption of certain conservation agricultural practices could help in reducing the CFP while maintaining productivity and better resource utilization.

Crop management practices like managing nitrogen application with crop demand, conservation tillage, residue incorporation, direct seeded rice, drip irrigation etc.

improves resource use efficiency by decreasing losses of inputs to the surrounding environment Integration of these improved farming practices together enables to reduce the use of inorganic fertilizers, increase the system productivity, and lower the carbon footprint. Farmers are increasingly aware that crop production is no longer a yield-income business, and the way the crops are produced will have significant environmental consequences. Over $60 \%$ of the total emissions in food products in grocery stores stem from farm gate raw material. Farmers play a key role in ensuring the provision of low-emission materials to the food chain. There are huge gaps between the development of new cropping technologies and the implementation of the technologies in farming operations. With relevant agro-environmental policies in place, along with the adoption of improved agronomical tactics, increasing food production with no cost to the environment can be achieved effectively, efficiently, and economically.

\section{References}

1. ICAR. ICAR; New Delhi, India: 2015. VISION 2020-Indian Council of Agricultural Research.

2. Saharawat YS, Singh B, Malik RK, Ladha JK, Gathala M, Jat ML, Kumar V. Evaluation of alternative tillage and crop establishment methods in a rice-wheat 
rotation in North Western IGP. Field Crops Res.2010; 116: 260-267.

3. INCCA. Indian Network for Climate Change Assessment, Ministry of Environment and Forests, Government of India; 2010. India: Greenhouse Gas Emissions 2007.

4. CTA-CCAFS. Technical Centre for Agricultural and Rural Cooperation ACPEU (CTA) and CGIAR Research Program on Climate Change, Agriculture and Food Security (CCFAS); 2011. Farming's Climate-smart Future: Placing Agriculture at the Heart of Climate-change Policy.

5. Pathak H, Jain N, Bhatia A, Patel J, Aggarwal PK. 2010. Carbon footprints of Indian food items. Agric. Ecosyst. Environ. 1-2:66-73.

6. Smith P, Haberl H, Popp A, Erb K-H, Lauk C, Harper R, Tubiello F, de Siqueira Pinto A, Jafari M, Sohi S, Masera O, Böttcher $\mathrm{H}$, Berndes $\mathrm{G}$, Bustamante $\mathrm{M}$, Ahammad H, Clark H, Dong HM, Elsiddig EA, Mbow C, RavindranathNH, Rice CW, Robledo Abad C, Romanovskaya A, Sperling F, Herrero M, House JI, Rose S. How much land based greenhouse gas mitigation can be achieved without compromising food security and environmental goals? GCB Bioenergy. 2013; 19:2285-2302.

7. Powlson DS, Stirling CM, Jat ML, Gerard BG, Palm CA, Sanchez PA, Cassman KG. Limited potential of no-till agriculture for climate change mitigation. Nat. Clim. Change. 2014; 4:678-683.

8. Government of India. 2015. India- First Biennial Update Report to the United Nations Framework Convention on Climate Change. Ministry of Environment, Forest and Climate Change, Government of India, New Delhi, India, $184 \mathrm{p}$.

9. Mandal DK, Mandal C, Singh SK. Delineating Agro-Ecological Regions. ICAR-NBSS\&LUP Technologies. 2016;
1-8.

10. Uttar Pradesh State Report - 2018. https://www.ibef.org/download/UttarPradesh-August-2018.pdf.

11. Agricultural Statistics.2017. Department of Agriculture \& Cooperation\& Farmers Welfare. Directorate of Economics \& Statistics New Delhi.

12. Paustian K, Lehmann J, Ogle S, Reay D, Robertson GP, Smith P. "Climate-Smart Soils.” Nature. 2016; 532: 49-57.

13. IPCC (Intergovernmental Panel on Climate Change). Climate Change 2007: Mitigation. Contribution of Working Group III to the Fourth Assessment Report of the Intergovernmental Panel on Climate Change, edited by B. Metz, O.R. Davidson, P. R. Bosch, R. Dave, and L. A. Meyer. Cambridge, UK: Cambridge University Press, 2007.

14. Russell-Smith J, Monagle C, Jacobsohn M, Beatty RL, Bilbao B, Millán A, Vessuri H, SánchezRose I. Can Savanna Burning Projects Deliver Measurable Greenhouse Emissions Reductions and Sustainable Livelihood Opportunities in Fire-Prone Settings? Climatic Change. 2017. 140: 47. DOI: $10.1007 / \mathrm{s} 10584-013$ 0910-5.

15. Kehlbachaer A, Tiffin R, Briggs A, Berners-Lee M, Scarborough P. The Distribution and Nutritional Impacts and Mitigation Potential of Emission-Based Food Taxes in the UK. Climate Change. 2016. 137: 121- 141.

16. GHG Platform-India. 2017. Trend Analysis of GHG Emissions in India from 2005 to 2013. Retrieved fromwww.ghgplatformindia.org/publications.

17. IPCC. 2006 IPCC Guidelines for National Greenhouse Gas Inventories: Glossary, Japan, 2006.

18. Reay SD, Davidson EA, Smith KA, Smith P, Melillo JM, Dentener F, Crutzen PJ. "Global Agriculture and Nitrous Oxide 
Emissions." Nature Climate Change. 2012; 2: 410-416.

19. FAO. Food security and agricultural mitigation in developing countries: options for capturing synergies. Rome 2009.

20. MoEF (Ministry of Environment and Forests). India: Greenhouse Gas Emissions 2007. New Delhi, 2010.

21. IPCC. Climate Change 2014: Synthesis Report. Contribution of Working Groups I, II and III to the Fifth Assessment Report of the Intergovernmental Panel on Climate Change, 2014.

22. FAO. 2016. FAOSTAT Agricultural Data. Accessed September 1, 2016. http://faostat.fao.org/

23. Ramachandra TV, Shwetmala. Decentralised carbon footprint analysis for opting climate change mitigation strategies in India. Renewable and Sustainable Energy Reviews, 2012; 16: 5820-5833.

24. Chakrabarty, S. 2018. By the Numbers: New Emissions Data Quantify India's Climate Challenge.

25. Lal R. Carbon emissions from farm operations. Environ Intern. 2004; 30: 981990.

26. Arora VK, Jalota SK, Singh KB. Managing water crisis for sustainable crop production in Punjab: Anoverview. J Res (Punjab AgricUniv); 2008; 45: 17-21.

27. Benbi DK, Kaur H, Toor AS. Carbon Footprint and Sustainability of Agriculture in Punjab. ICAR National Professor Chair, Punjab Agricultural University, Ludhiana 141 004, India, 2019, p. 75.

28. IPCC (Intergovernmental Panel on Climate Change). Climate Change 2013: The Physical Science Basis. Contribution of Working Group I to the Fifth Assessment Report of the Intergovernmental Panel on Climate Change. Stocker, T.F., et al., (eds.).
Cambridge University Press, Cambridge, United Kingdom and New York, NY, USA, 2013.

29. Garg A, Shukla PR, Upadhyay J. N2O emissions of India: an assessment of temporal, regional and sectoral trends. Climatic Change. 2012; 110: 755-782.

30. Andreae MO, Merlet P. Emission of trace gases and aerosols from biomass burning. Glob Biogeochem Cycles. 2001; 15: 955966.

31. Gadde B, Bonneta S, Menke C, Garivait S. Air pollutant emissions from rice straw open field burning in India, Thailand and the Philippines. Environ Poll. 2009; 157: 1554-1558.

32. Pathak H, Bhatia A, Jain N. Greenhouse Gas Emission from Indian Agriculture: Trends, Mitigation and Policy Needs. Indian Agricultural Research Institute, New Delhi, 2014; p39.

33. Pathak H, Jain N, Bhatia A, Patel J, Aggarwal PK. Carbon footprints of Indian food items AgricEcosys Environ. 2010; 139: 66-73

34. Patra NK, Babu SC. Mapping Indian Agricultural Emissions. Lessons for Food System Transformation and Policy Support for Climate-Smart Agriculture. IFPRI Discussion Paper 01660, 2017.

35. Sapkota TB, Vetter SH, Jat ML, Sirohi S, Shirsath PB, Singh R, Jat HS, Smith P, Hillier J, Stirling CM. Cost-effective opportunities for climate change mitigation in Indian agriculture. Science of the Total Environment. 2019; 655: 1342-1354.

36. Annual report 2018-19. Govt. of India Ministry of Chemicals \& Fertilizers. https://chemicals.nic.in/sites/default/files/ annual\%20report\%20201819\%20eng.pdf.

37. IBEF. 2019. Industrial Development \& Economic Growth in Uttar Pradesh. www.ibef.org.

38. Tirado R, Gopikrishna SR, Krishnan R, 
Smith P. Greenhouse gas emissions and mitigation potential from fertilizer manufacture and application in India. International Journal of Agricultural Sustainability. 2010; 8(3): 176-185.

39. FAI, 'Fertiliser Association of India: Fertiliser Statistics2006-07', prepared by T. K. Chanda, Kuldeep Sati,C. Robertson, New Delhi. 2007.

40. Mishra V, Asoka A, Vatta K, Lall U. Groundwater Depletion and Associated $\mathrm{CO}_{2}$ Emissions in India. Earth's Future, 2018; 6: 1672-1681.

41. Jain N, Bhatia A, Pathak H. Emission of Air Pollutants from Crop Residue Burning in India. Aerosol and Air Quality Research, Indian council of food and agriculture. Crop residue burning problems and solutions. 2014;14: 422430.

42. MOSPI, 201314,http://www.mospi.gov.in/announceme nts/asi-2013-14-vol-i

43. Ali MA, Inubushi K, Kim PJ, Amin S. Management of Paddy Soil towards Low Greenhouse Gas Emissions and Sustainable Rice Production in the Changing Climatic Conditions. Soil Contamination and Alternatives for Sustainable Development Book. DOI: 10.5772/intechopen.83548, 2019.

44. Gupta, PK, Gupta V, Sharma C, Das SN, Purkait N, Adhya TK, Pathak H, Ramesh R, Baruah KK, Venkatratnam L, Singh G, Iyer CSP. Development of methane emission factors for Indian paddy fields and estimation of national methane budget. Chemosphere, 2009; 74: 590598.

45. Pathak H, Li C, Wassmann, R. Greenhouse gas emissions from Indian rice fields: calibration and upscaling using the DNDC model. Biogeosciences Discussions, 2005; 2: 77-102.

46. Kumar V, Jana S, Bhardwaj A, Deepa R, Sahu SK, Pradhan PK, Sirdas SA.
Greenhouse Gas Emission, Rainfall and Crop Production over North-Western India. The Open Ecology Journal. 2018; 11: 47-61.

47. DoES, Department of Economic and Statistics, Government of India. http:// eands. dacnet.nic.in (accessed October 2016), 2016.

48. Hiloidhari M, Araújo K, Kumari S, Baruah DC, Ramachandra TV, Kataki R, Thakur IS. Bioelectricity from sugarcane bagasse co-generation in India-An assessment of resource potential, policies and market mobilization opportunities for the case of Uttar Pradesh. Journal of Cleaner Production. 2018; 182: 10121023.

49. Indian Sugar Mills Association, 2016. http://www.indiansugar.com/PDFS/Cogen erators.pdf. (Accessed January, 2016).

50. Singh and Sharma. Mitigating Greenhouse Gas-Carbon Dioxide through Sugarcane Cultivation. Centennial Fiesta, National symposium on "challenges, opportunities and innovative approaches in sugarcane: Agriculture, Bio-energy and climate change: U.P. Council of sugarcane research, Shahjahanpur, 2016.

51. Misra V, Shrivastava AK, Mall AK, Solomon S, Singh AK, Ansari MI. Can sugarcane cope with increasing atmospheric $\mathrm{CO}_{2}$ concentration? Aust J Crop Sci. 2019; 13(05): 780-784.

52. Cooperative Sugar, 2014, 45, 9, May 2014; Uttar Pradesh.

53. Sharma BR, Gulati A, Mohan G, Manchanda S, Ray I, Amarasinghe U. Water productivity mapping of major Indian crops.

54. Gan Y, Liang C, Wang X, and McConkey B. Lowering carbon footprint of durum wheat by diversifying cropping systems. Field Crop Res. 2011. 122:199-206.

55. Yan M, Luo $\mathrm{T}$, Bian $\mathrm{R}$ et al., $\mathrm{A}$ comparative study on carbon footprint of rice production between household and 
aggregated farms from Jiangxi, China. Environ Monit Assess 2015. 187:332. doi:10.1007/s10661-015- 4572-4579.

56. Pathak H, Bhatia A, Prasad S, Singh S, Kumar S, Singh J, Jain MC,Kumar U. Emission of nitrous oxide from ricewheat systems of Indo-Gangetic plains of India. Environ. Monit. Assess. 2002; 77: 163-178.

57. Pathak H, Prasad S, Bhatia A, Singh S, Kumar S, Singh J, Jain MC. Methane emission from rice-wheat cropping system in the Indo-Gangetic plain in relation to irrigation, farmyard manure and dicyandiamide application. Agric. Ecosyst. Environ. 2003; 97:309-316.

58. Pathak H, Saharawat YS, Gathala M, Mohanty S, Ladha JK. Simulating environmental impact of resourceconserving technologies in the rice-wheat system of the Indo-Gangetic Plains. In: Ladha, JK, Yadvinder-Singh, Erenstein O, Hardy B. (Eds.), Integrated crop and resource management in the rice-wheat system of South Asia. International Rice
Research Institute, Los Ba nos (Philippines), 2009; pp. 321-334.

59. Pinheiro ÉFM, de Campos DVB, de Carvalho BF, dos Anjos LHC, and Pereira MG. Tillage systems effects on soil carbon stock and physical fractions of soil organic matter. AgricSyst. 2015; 132:3539.

60. Hu F, Chai Q, Yu A, Yin W, Cui H, Gan Y. Less carbon emissions of wheat-maize intercropping under reduced tillage in arid areas. Agron Sustain Dev. 2015; 35:701711.

61. Maheswarappa HP, Srinivasan V, Lal R. Carbon footprint and sustainability of agricultural production systems in India. $\mathbf{J}$ Crop Improvement. 2011; 25:303-322.

62. Sainju UM, Jabro JD, Caesar-TonThat T. Tillage, cropping sequence, and nitrogen fertilization effects on dryland soil carbon dioxide emission and carbon content. J Environ Qual. 2010; 39:935-945.

\section{How to cite this article:}

Sharath Chandra, M., R.K. Naresh, Pradeep Rajput, Pebbeti Chandana, Pradeep Kumar Singh and Shivashankar, K. 2020. Carbon Footprint as Prominent Indicator of Agricultural Sustainability in Diverse Agro-climatic Zones of Northern India: A Critical Review. Int.J.Curr.Microbiol.App.Sci. 9(11): 3077-3102. doi: https://doi.org/10.20546/ijcmas.2020.911.373 